\title{
THE
}

\section{The 2005 Chios Ancient Shipwreck Survey: New Methods for Underwater Archaeology}

\author{
Brendan P. Foley \\ Katerina Dellaporta \\ Dimitris Sakellariou \\ Brian S. Bingham \\ Richard Camilli
}

See next page for additional authors

Follow this and additional works at: https://digitalcommons.uri.edu/gsofacpubs

Part of the History of Art, Architecture, and Archaeology Commons, Ocean Engineering Commons, and the Robotics Commons

Terms of Use

All rights reserved under copyright.

\section{Citation/Publisher Attribution}

Foley, B. P., Dellaporta, K., Sakellariou, D., Bingham, B. S., Camilli, R., Eustice, R. M., Evagelistis, D., Ferrini, V. L., Katsaros, K., Kourkoumelis, D., Mallios, A., Micha, P., Mindell, D. A., Roman, C., Singh, H., Switzer, D. S., and Theodoulou, T. (2009). The 2005 Chios Ancient Shipwreck Survey: New Methods for Underwater Archaeology. Hesperia: The Journal of the American School of Classical Studies at Athens, Vol. 78, No. 2 (Apr. - Jun., 2009), pp. 269-305.

Available at: http://www.jstor.org/stable/25622694

This Article is brought to you for free and open access by the Graduate School of Oceanography at DigitalCommons@URI. It has been accepted for inclusion in Graduate School of Oceanography Faculty Publications by an authorized administrator of DigitalCommons@URI. For more information, please contact digitalcommons-group@uri.edu. 


\section{Authors}

Brendan P. Foley, Katerina Dellaporta, Dimitris Sakellariou, Brian S. Bingham, Richard Camilli, Ryan M.

Eustice, Dionysis Evagelistis, Vicki Lynn Ferrini, Kostas Katsaros, Dimitris Kourkoumelis, Aggelos Mallios,

Paraskevi Micha, David A. Mindell, Christopher Roman, Hanumant Singh, David S. Switzer, and Theotokis

Theodoulou

This article is available at DigitalCommons@URI: https://digitalcommons.uri.edu/gsofacpubs/3 
HESPERIA 78 (2009)

Pages 269-305

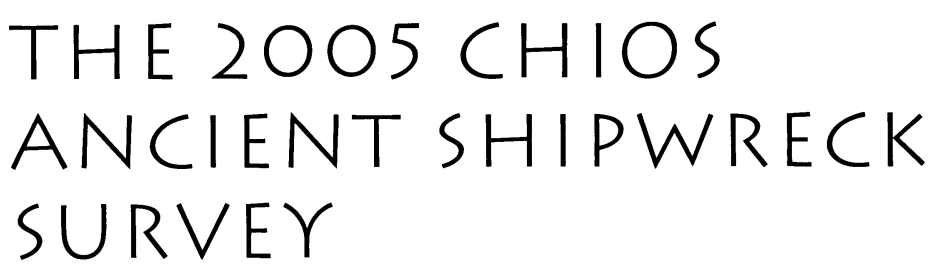

New Methods for Underwater Archaeology

\begin{abstract}
In 2005 a Greek and American interdisciplinary team investigated two shipwrecks off the coast of Chios dating to the 4th-century B.c. and the $2 \mathrm{nd} / 1 \mathrm{st}$ century. The project pioneered archaeological methods of precision acoustic, digital image, and chemical survey using an autonomous underwater vehicle (AUV) and in-situ sensors, increasing the speed of data acquisition while decreasing costs. The AUV recorded data revealing the physical dimensions, age, cargo, and preservation of the wrecks. The earlier wreck contained more than 350 amphoras, predominantly of Chian type, while the Hellenistic wreck contained about 40 Dressel 1C amphoras. Molecular biological analysis of two amphoras from the 4th-century wreck revealed ancient DNA of olive, oregano, and possibly mastic, part of a cargo outbound from Chios.
\end{abstract}

\title{
INTRODUCTION
}

In the summer of 2004 during an archaeological and geological-geophysical survey in the Chios Strait, archaeologists of the Hellenic Ephorate of Underwater Antiquities (EUA) and oceanographers of the Hellenic Centre for Marine Research (HCMR) discovered the remains of a 4th-century в.c. shipwreck (Chios wreck A) between Chios and Oinousses. ${ }^{1}$ Recognizing the significance of the wreck's side-scan and sub-bottom sonar signatures, the team deployed the HCMR Super Achilles remotely operated vehicle (ROV) to collect video images of the site. EUA maritime archaeologists reviewed the video and confirmed the archaeological importance of the wreck. ${ }^{2}$ After the Greek scientists made the initial discovery and characterization of the

1. There are multiple shipwrecks around Chios, so for the sake of clarity we have chosen to apply an alphabetic naming convention in this article. The EUA officially uses a different naming convention for shipwrecks, relying on the names of nearby geographical points. In the EUA naming convention, Chios wreck $A$ is the Chios-Oinousses wreck and Chios wreck $\mathrm{B}$, described below, is the Lithi wreck.

A number of acronyms are used in the text. Some that may be unfamiliar to archaeologists include CDOM (chromophoric dissolved organic matter), DVL (Doppler velocity log), and LBL (long baseline). For these and others, the full term is spelled out upon first mention.

2. Sakellariou et al. 2007 , pp. 371,

(C) The American School of Classical Studies at Athens 
site, they contacted personnel at the Woods Hole Oceanographic Institution (WHOI). Together, in 2005, the international team jointly planned and conducted a survey of the site using an autonomous underwater vehicle (AUV). Preliminary investigations of a second, later wreck (Chios wreck B), located off the western coast of Chios, were also carried out.

We present here the results from this innovative archaeological shipwreck survey, conducted with an autonomous underwater robot carrying in-situ sensors. Chios wreck $A$ lies at a depth of $70 \mathrm{~m}$, deeper than is feasible to explore with scuba equipment. We do not expect that divers will ever visit this site, and therefore we sought to use this project to determine the present limits of underwater remote sensing for archaeological purposes. One of the project goals was to extract useful archaeological information from the site as rapidly as possible, while leaving the site undisturbed. We believe that this approach presents a new paradigm for maritime archaeological investigations, for it will enable study of large numbers of directly comparable sites spread over a wide geographic range. With these powerful new technologies and survey methods, underwater landscape archaeology becomes possible.

In the pages that follow, we attempt to reach across academic and scientific disciplines in order to engage broad audiences in the humanities as well as scientific and engineering fields. Our intent is to alert archaeologists to new methods and to catalyze new approaches to shipwreck investigations. At the same time, we wish to pique the interest of engineers and physical scientists in the hope of stimulating future collaborations with social scientists. We begin with a detailed explanation of the technologies and methods involved in this type of survey. To establish a professional standard of quality for other investigators interested in deepwater archaeology, we compare the precision of the measurements obtained in the 2005 project to accepted professional shallow-water practice. In the following section, we describe technologies enabling environmental sensing and the prediction of the state of preservation of wrecks and their artifacts. We next present the archaeological information obtained from Chios wreck $A$ and our interpretation of the findings, with special attention given to the large cargo of amphoras and their contents. Finally, we conclude with a vision for underwater archaeology's future.

Scuba-based underwater archaeology is limited to shallow waters (less than $50 \mathrm{~m}$ ), leaving approximately $98 \%$ of the seafloor out of reach. Deeper coastal waters hold vast numbers of shipwrecks, and historical data indicate that the seafloor far offshore contains $20 \%-23 \%$ of all wrecks. ${ }^{3}$ The large number of wrecks is only one attractive aspect of deepwater archaeological survey. Our experiences have shown that deepwater wrecks typically are better preserved than those in shallow water because they are immune to disturbance from surface waves and from intrusion by divers. Unlike shallow-water wrecks, artifacts lying beyond the phototropic zone (ca. $100 \mathrm{~m}$ ) typically have little or no marine growth on them, allowing for easier visual identification.

A compelling reason to investigate deepwater sites is the possibility of encountering completely novel archaeological information. It remains an open question whether specialized long-haul ships carried bulk cargoes across ancient open-water routes. We know from ancient texts

3. Data compiled from Walker 1848. 
that large grain carriers moved enormous quantities of foodstuffs across the Mediterranean during the Roman period, though we have yet to discover a wrecked grain ship. ${ }^{4}$ These vessels are somewhat analogous to modern oil supertankers and container ships, which are designed to ply ocean routes with minimal time spent in port or near shore. The wrecks of ancient long-distance vessels may best be sought in their natural deepwater environment. Future investigations may demonstrate that the near-shore and offshore seafloors contain wrecks of divergent vessel types carrying different cargoes.

To gain access to shipwrecks in deep water, archaeologists occasionally have partnered with ocean scientists and engineers to use an ROV or human occupied vehicle (HOV). ${ }^{5}$ These projects have demonstrated the strengths of submersible vehicle operations for archaeology: the speed, accuracy, and repeatability with which mapping and photographic surveys can be accomplished, and a capability for robotic manipulation and recovery of artifacts.

Reliance on these systems, however, is problematic for several reasons. The costs of ROV and HOV operations are high due to the capital and operational expenses of the technology and the day rate for the dedicated oceanographic research vessels necessary to support the systems. ROVs require a cable connection to the surface ship and an expensive and heavy level-winding winch to carry the cable on the ship. When using ROVs in deep water, the support vessel must be equipped with a dynamic positioning system, a system that uses computers to control and coordinate the ship's thrusters and propellers. Position fixes from a global positioning system (GPS) are fed to the computer, which then directs the ship to hover within a few meters of its intended position on the sea surface, preventing unintended vessel movement from pulling the ROV off-site. ${ }^{6}$ Dynamic positioning ships are very expensive to charter. American research vessels with dynamic positioning cost approximately $\$ 40,000$ per day, while commercial dynamic positioning vessels can cost as much as $\$ 100,000$ per day. The number of ROVs and HOVs suitable for archaeological use is low, limiting the number of projects that can be undertaken. Because of these factors and others, archaeologists rarely employ these technologies.

Free-swimming robotic AUVs offer solutions to some of these problems and open new opportunities for archaeological exploration in both deep and shallow waters. Because AUVs have no tether, they do not require dedicated dynamic positioning vessels. Nearly any vessel can support these operations, bringing vessel charter costs down to $\$ 10,000-\$ 20,000$ per day, or even less. We foresee, within the next few years, deployment of AUVs from shore, entirely eliminating the need for the support ship. While longrange AUVs navigate deep waters for large-area and site-specific survey, small AUVs can perform daily mapping and photography over sites at diver depth, freeing archaeologists from these time-consuming functions. AUV technology is maturing, and the number of vehicles available worldwide is steadily increasing. As archaeologists adopt the use of AUVs, we will gain access to substantially more submerged sites. The project described here is one of the first to employ AUVs for archaeological purposes, and it points to a promising direction for archaeology under water. p. 555

4. For a discussion of the size of Roman vessels, with references to ancient texts, see Houston 1988.

5. Ballard et al. 2000, 2002;

McCann and Oleson 2004.

6. Mindell and Bingham 2001, 

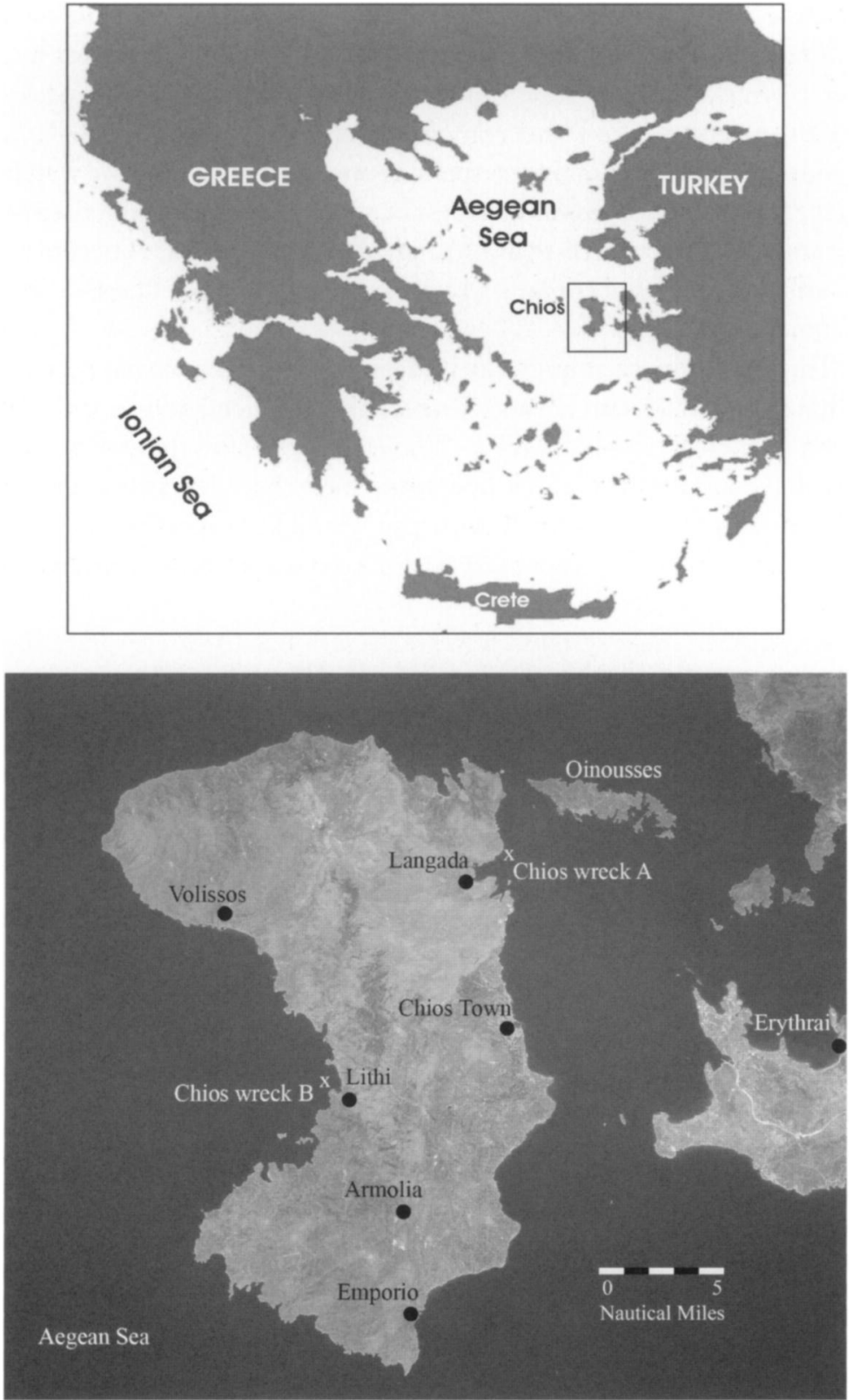

\section{METHODS AND TECHNOLOGY}

\section{Overview of the Survey}

As noted above, Chios wreck $A$ is located in the strait between Chios and Oinousses, roughly a kilometer from the shore near the village of Langada (Fig. 1). ${ }^{7}$ The wreck is embedded in a flat, silty seafloor in approximately $70 \mathrm{~m}$ of water. The team selected this wreck for AUV survey because it is archaeologically significant, its depth exceeds conventional scuba diving limits, and the flat seafloor is a benign environment for AUV robotic operations.

Survey by AUV is a new approach to archaeological site investigation. To test the technology and develop methods for its use, the team budgeted
Figure 1. Overview and detail showing location of the 2005 Chios shipwreck surveys and other sites mentioned in the text. Original photo (STS078-732-53) courtesy the Image Science and Analysis Laboratory, Johnson Space Center, NASA; adapted by B. P. Foley
7. Near Langada is the Classical farm site of Delphinion: Garnett and Boardman 1961, p. 106; Yalouris 1986, pp. 157, 163, 166. 
eight days of ship time to complete the survey of the 4th-century B.c. wreck, deeming that period sufficient to overcome any equipment failures. Fortunately, weather conditions were ideal and the AUV performed to expectations. We completed operations on the Chios wreck A site within three calendar days, and all AUV operations within 24 hours. With the remaining ship time, we conducted additional investigations in the Chios Strait: side-scan sonar and sub-bottom profiling sonar surveys, and video examination (with the HCMR ROV) of geological features and a modern-era shipwreck site.

After survey of the Classical-period wreck and three days of operations in the Chios Strait, the team moved to the western side of Chios, near the village of Lithi, to investigate reports of a Roman wreck (Chios wreck B) that was thought to date to the 4th century A.D. We deployed the ROV, located the wreck site at depths of 36-42 m, and conducted AUV and diver operations at the site (Fig. 1). Based on the style of amphoras observed on Chios wreck B, the site dates not to the 4th century A.D., but to the late 2nd/early 1 st century в.c.

\section{The Autonomous Underwater Vehicle and OnBOARD SENSORS}

The AUV deployed for the Chios project measures less than $2 \mathrm{~m}$ long and $2 \mathrm{~m}$ high, and is lightweight (approximately $200 \mathrm{~kg}$ ). This allows it to be deployed from a wide variety of vessels, including small coastal craft or fishing boats (Fig. 2). The robot's flotation and a pressure housing containing computers are mounted in an upper hull, while its batteries and other heavy components are mounted in a lower hull. The two hulls are connected by struts, upon which are mounted two fore-and-aft thrusters. The lower hull contains a vertical thruster. This double-body arrangement separates the center of buoyancy from the center of gravity, so the robot is passively stable in pitch and roll. Combined with precise control of multiple thrusters, passive stability grants the AUV capability for extremely slow-motion operation, thereby allowing dense data collection during surveys. ${ }^{8}$

Three types of sensors were on board the AUV during the 2005 survey: navigation sensors for real-time positioning and guidance, optical and sonar sensors for mapping the seafloor and its features, and in-situ chemical sensors for quantifying the oceanographic environment. ${ }^{9} \mathrm{~A}$ downward-facing digital camera was mounted forward in the lower hull of the robot, and its single synchronized incandescent strobe light was positioned aft in the lower hull. This arrangement optimized camera-to-light separation, reducing optical backscatter in the digital images. A multibeam mapping sonar was mounted just aft of the camera, and the DVL deadreckoning navigation and altimetry sonar was fixed in the rear of the lower 295.

8. Singh et al. 2004, pp. 289, 294-

9. Navigation sensors included Teledyne Benthos 6000 Series long baseline (LBL) transponders, a Teledyne RD Instruments $1200 \mathrm{kHz}$ Doppler velocity $\log$ (DVL), and an IXSEA Octans fiber-optic gyrocompass. The optical and sonar payload sensors were a Cooke Corporation Pixelfy 12-bit 1.2 megapixel single-chip color digital camera with synchronized strobe, and an Imagenex Delta $\mathrm{T}(260 \mathrm{kHz})$ multibeam imaging sonar. The in-situ chemical payload sensors consisted of a Sea-Bird Electronics SBE49 conduc- tivity-depth-temperature (CDT) sensor; Chelsea Technologies Group Aquatracka aromatic hydrocarbon fluorometer; Seapoint Sensors chlorophyll fluorometer; and a Seapoint Sensors chromophoric dissolved organic matter (CDOM) fluorometer. 


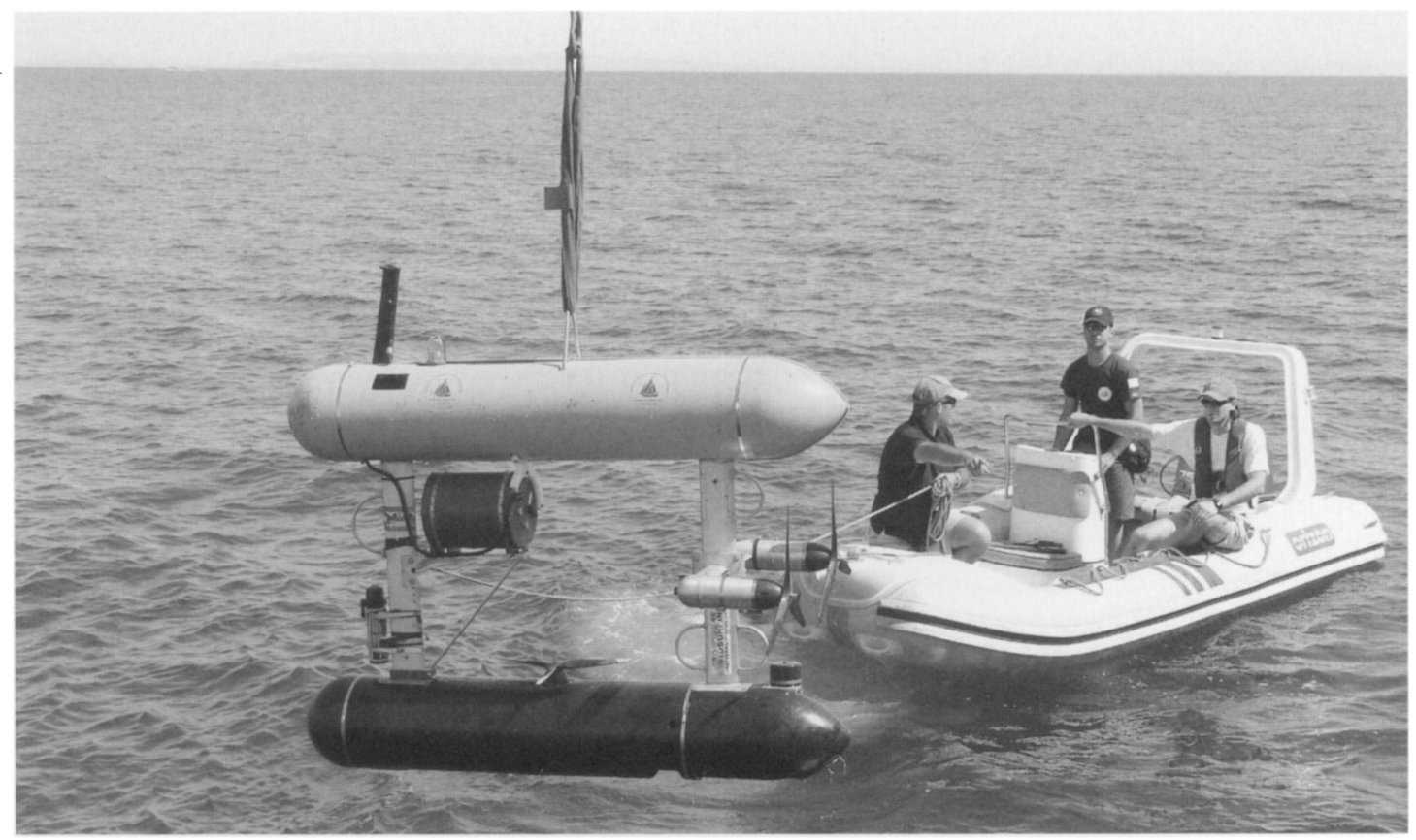

hull. ${ }^{10}$ Chemical sensors mounted within the lower hull measured salinity, temperature, chlorophyll, chromophoric dissolved organic matter (CDOM), and aromatic hydrocarbons. Because all of these sensors were incorporated into a single, passively stable, precisely navigated platform, the resulting coregistered data sets could be overlaid, thus enhancing interpretation and understanding of the wreck and its environment.

\section{Precision Autonomous Navigation for Archaeology}

Precision navigation makes possible the coordination of observations from multiple sensors into accurately overlaid maps, transforming purely observational exploration into systematic scientific investigation. ${ }^{11}$ The requisite positioning precision of the underwater vehicle varies depending on sensors and data products. The navigation system's functional requirements for archaeological site investigations off Chios are as follows:

1. The AUV positioning must be sufficiently accurate to locate the wreck site on the seafloor at the beginning of each survey, i.e., the absolute real-time horizontal positioning must be accurate to within $3 \mathrm{~m} .{ }^{12}$ This was achieved through LBL

10. The DVL takes advantage of the Doppler effect to estimate velocity over the seafloor. For a full explanation, see Gordon 1996.

11. Singh, Whitcomb, et al. 2000, pp. 144-145.

12. We quantify the actual value of this design goal based on the notion of circular error probability (CEP), the radius of a circle defining the $50 \%$ confidence in the AUV's position. We define our desired position accuracy based on the footprint of our initial AUV missions, the expected spatial extent of the wreck site, and the desire to ensure that each mission completely covers the target location. The chosen parameter of $3 \mathrm{~m} \mathrm{CEP}$
Figure 2. The SeaBED autonomous underwater vehicle, operated by the Deep Submergence Laboratory of the Woods Hole Oceanographic Institution. In four missions conducted within a 24-hour period, the AUV mapped multiple parameters of Chios wreck A. Photo M. Grund

provides a $95 \%$ confidence that the survey will be centered within $6.3 \mathrm{~m}$ of the target location. This method implicitly assumes that there is zero bias in our positioning uncertainty. This assumption is justified by the fact that $\mathrm{LBL}$ acoustic positioning is a relative absolute GPS reference. 
acoustic positioning, capable of absolute repeatability of approximately $1 \mathrm{~m} .{ }^{13}$

2. The AUV must have sufficiently precise guidance to survey the wreck site with guaranteed optical and sonar sensor overlap, i.e., the real-time guidance must be capable of positioning adjacent tracklines with a relative uncertainty of less than $0.35 \mathrm{~m} .{ }^{14}$ The Chios survey used precise dead-reckoning, combining DVL measurements and Octans fiber-optic gyroscope heading reference to estimate position. For the $30 \times 45 \mathrm{~m}$ fine-resolution wreck survey, we consider the relative position uncertainty between the start and end points of adjacent tracklines as a worst-case scenario. The estimated standard deviation for the real-time positioning of the start and end points of adjacent tracklines is $0.26 \mathrm{~m} .{ }^{15}$ This translates to an $80 \%$ confidence interval for satisfying the $0.35 \mathrm{~m}$ requirement.

3. For AUVs to be useful for archaeology, the precision and accuracy of the final data product must be comparable to the state of the art in underwater archaeology, i.e., the post-processed accuracy of the localization solution should be within $0.10 \mathrm{~m}$ in three dimensions.

Compared to the direct survey method, the professional standard for mapping underwater archaeological sites, the AUV navigation results are acceptable. The direct survey method uses fiberglass tape measurements of multiple distances to various datum points. These measurements are combined via three-dimensional trilateration to estimate position. ${ }^{16} \mathrm{~A}$ thorough consideration of the uncertainty in this standard technique shows that positions can be determined to within $0.043 \mathrm{~m}$ ( $95 \%$ confidence), but human mistakes can lead to gross errors in $20 \%$ of the measurements (outliers). ${ }^{17}$ The Chios survey utilized an off-line combination of LBL absolute positioning with DVL dead-reckoning. The final navigational data product from the Chios surveys has a positioning uncertainty of approximately $0.145 \mathrm{~m}$ with $95 \%$ confidence, ${ }^{18}$ higher than the best-case direct survey method results. ${ }^{19}$

Because both the real-time and off-line (post-processing) navigation measurements rely on the combination of redundant and complementary sensing modalities, the AUV survey execution is robust with respect to outliers in measurement. The vehicle autonomously filters the data in real time to remove spurious observations. The post-processing algorithms also remove any measurement errors. We believe this increase in uncertainty over

13. Whitcomb et al. 2000 , p. 442.

14. This requirement is based on a $1.85 \mathrm{~m}$ across-track image footprint and a $1.5 \mathrm{~m}$ trackline spacing. See the fine-resolution survey described below.

15. We estimate the dead-reckoning position uncertainty using a measurement model for the combination of DVL velocity and Octans heading reference. The DVL velocity measure- ment standard deviation is $3 \mathrm{~mm} / \mathrm{s}$, and the Octans heading accuracy standard deviation is $0.1^{\circ}$ secant latitude. Deadreckoning uncertainty is time dependent and nonlinear. The uncertainty is constrained to less than $0.3 \%$ of distance traveled (using a simple random walk model integrating survey velocity of $0.2 \mathrm{~m} / \mathrm{s}$ at $38^{\circ}$ north latitude for distances greater than $75 \mathrm{~m}$ ). This metric of $0.3 \%$ distance traveled is only applicable because the heading reference uncertainty tends to dominate the position uncertainty on these scales.

16. Rule 1989.

17. Holt 2003, p. 251.

18. Based on $0.074 \mathrm{~m}$ standard deviation.

19. Bingham 2003. 
the direct survey method is acceptable for four reasons: the site remained undisturbed by the survey, allowing for future repeated investigations; the resulting positioning is absolute and referenced to GPS coordinates; the positioning data range over a larger spatial area and at a greater depth than is realistically feasible using the direct survey method; and the navigational precision and accuracy were sufficient to generate useful site maps.

\section{Shipwreck Surveys off Chios}

The survey of the 4th-century B.c. Chios wreck A consisted of four AUV missions. Repeatable absolute positioning within a stable reference frame provided a common coordinate space among missions. As the team's understanding of the site improved, efforts focused on increasingly finer-scale surveys to generate new awareness and knowledge of the site. For example, bathymetry measurements from the first survey informed subsequent surveys, allowing for a gradual increase in the resolution of the investigation. Chemical and optical data collected in later surveys could be overlaid on early bathymetric maps because the positioning was consistent in each of the missions.

During the first investigation phase, the team deployed the HCMR Super Achilles ROV on the GPS coordinates recorded in 2004 and relocated the wreck. With the site's location reestablished, the team moored LBL transponders on the seafloor near the wreck in a geometry that optimized the accuracy of the long baseline solution. Once these transponders were deployed, the team surveyed their actual locations by repeatedly interrogating the range and bearing of the transponders from the surface ship while recording the ship's GPS position. The resulting GPS locations of each transponder on the seafloor established a stable, global coordinate frame for all subsequent observations. Figure 3 shows the layout of the LBL transponders and the AUV positions in meters measured from an established latitude and longitude origin. This local coordinate frame is a Mercator projection relative to this fixed point, and it allows for easier navigational data processing while providing an absolute GPS coordinate reference. ${ }^{20}$

After locating the site with the ROV and placing seafloor transponders from the ship, the team initiated the second survey phase: a large-area reconnaissance intended to document the wreck's environmental context. During this coarse investigation, the AUV collected photographic, bathymetric, and chemical observations over an area of $50 \times 100 \mathrm{~m}$. The duration of this AUV dive was nearly three hours. This initial AUV mission established the location of the wreck within the local LBL coordinate system and provided an opportunity for an empirical check of the AUV's camera settings and lighting. After recovering the AUV, the team reviewed the images collected during the dive and refined the camera settings and survey plan in preparation for the second mission.

The third and final survey phase consisted of three fine-resolution AUV missions in order to produce comprehensive digital imaging, multibeam sonar, and chemical maps of the wreck and the seafloor immediately
Figure 3 (opposite). (a) LBL transponder layout in relation to wreck site, and (b) position of wreck within LBL network showing precisionnavigated tracklines of AUV based on comparative position data from LBL, DVL, and LBL/DVL combination. B. S. Bingham

20. We measure survey positions based on the World Geodetic System 1984 (WGS-84), using the standard GPS geodetic coordinates of latitude, longitude, and height. 
LBL /DVL Navigation
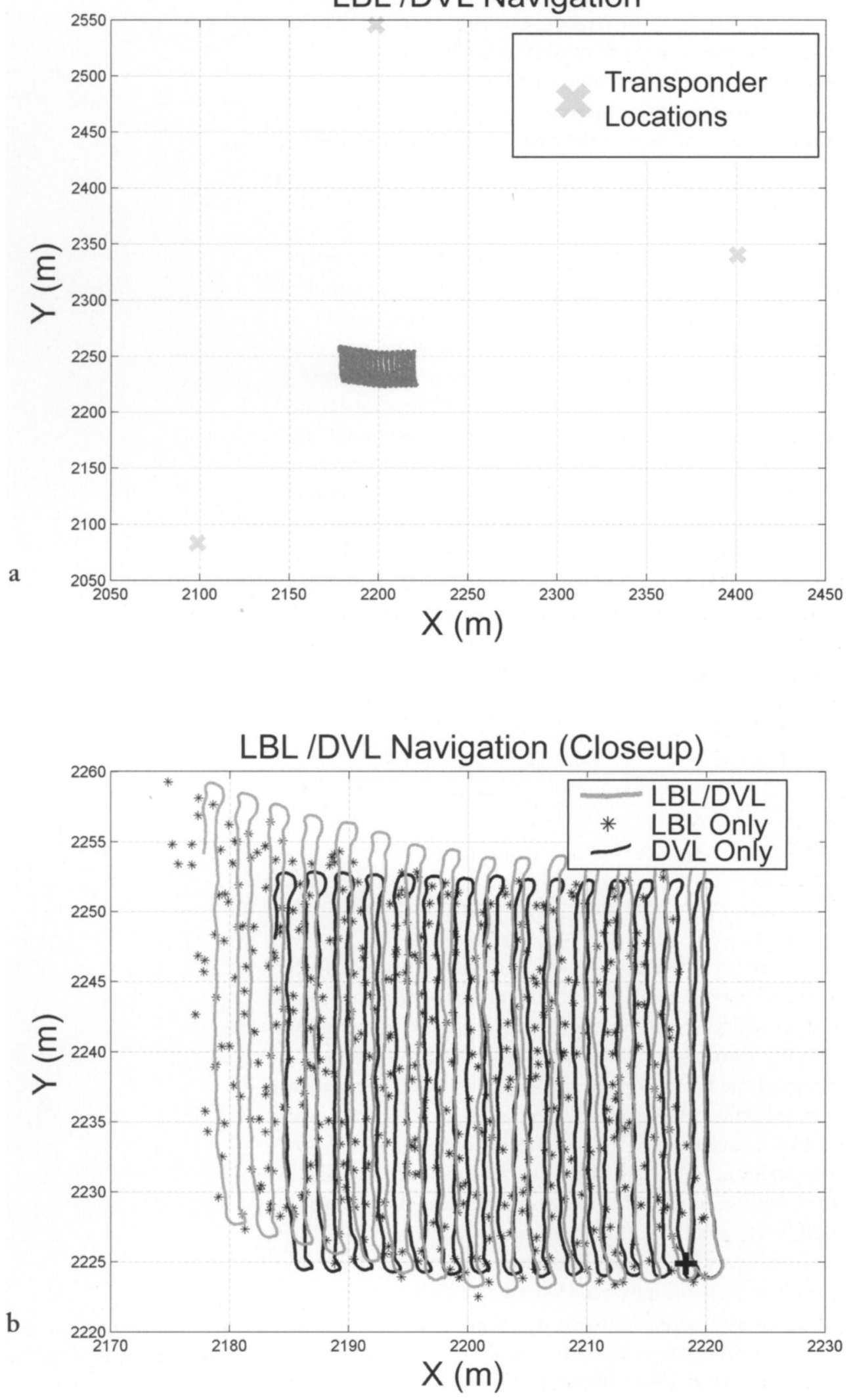
surrounding it. The relatively small scale of the site and its artifacts dictated positioning precision sufficient to resolve fine features (i.e., features $<0.10 \mathrm{~m}$ ). To produce photomosaics, this resolution is primarily a function of the optical camera parameters, the resolution of individual images, and the camera's distance from the seafloor. For most forms of bathymetric and chemical observations, the resolution of the final map is dependent upon sensor parameters, survey parameters, and positioning accuracy.

To obtain fine-resolution data, the team again programmed the AUV to swim in grid patterns over the wreck at an altitude of $2.5 \mathrm{~m}$, collecting overlapping data as the vehicle transited over the site at four different orientations. The total area of coverage during the survey was $30 \times 45 \mathrm{~m}$, centered on the wreck site. The AUV's speed over ground was $0.20 \mathrm{~m}$ per second, or 0.39 knots. The AUV's camera collected images every three seconds, synchronized with its strobe light. At an altitude of $2.5 \mathrm{~m}$, the camera footprint on the seafloor was approximately $1.50 \mathrm{~m}$ along-track by $1.85 \mathrm{~m}$ across-track. This altitude, image collection rate, and speed over ground resulted in approximately $60 \%$ overlap along-track in successive images. Tracklines were spaced $1.5 \mathrm{~m}$ apart, theoretically providing a $20 \%$ digital image overlap in adjacent tracks. The multibeam sonar collected data continuously throughout the mission, with an average swath width of $5 \mathrm{~m}$ providing more than $100 \%$ overlap between adjacent tracks. Onboard environmental sensors measured water temperature, salinity, aromatic hydrocarbons, concentrations of dissolved organic matter, and chlorophyll levels.

TABLE 1. DURATION OF AUV MISSIONS

\begin{tabular}{cc}
\hline AUVMission & Duration (br:min) \\
\hline 1 & ca. $03: 00$ \\
2 & $02: 42$ \\
3 & $02: 19$ \\
4 & $01: 23$ \\
\hline
\end{tabular}

These successive survey missions, of varying duration (Table 1), resulted in more than 7,000 high-resolution digital images of the wreck and surrounding seafloor. After color correcting and histogram equalizing the raw digital images, the team assembled photomosaic strips of the wreck site. ${ }^{21}$ Partial mosaics of the wreck were in the hands of the archaeologists within hours of data collection. At the same time, the engineering team used the information derived from the AUV's multibeam sonar and navigation sensors to generate preliminary bathymetric maps of the wreck site. With these data, the survey was complete, and the archaeological interpretation of the Chios wreck A site and its features commenced.

After conducting a few days of side-scan sonar surveys and ROV inspection of sonar targets in the Chios Strait, the team shifted operations to the western side of Chios to investigate the reported but undocumented Roman-era shipwreck, Chios wreck B. As noted above, we deployed the $\mathrm{ROV}$ and located the site at depths ranging from 36 to $42 \mathrm{~m}$. This site
21. Singh, Adams, et al. 2000; Pizarro and Singh 2003; Singh, Howland, and Pizarro 2004. 
Figure 4. Dressel 1C (Will Type 5) amphora, with detail of an incuse stamp on its rim, recovered by divers from the Hellenistic wreck B site off Lithi, Chios. Photo P. Vezirtis; drawing E. P. Oberlander
22. Peacock and Williams 1986 , p. 91; McCann et al. 1987, pp. 201203; Sciallano and Sibella 1991, p. 34.
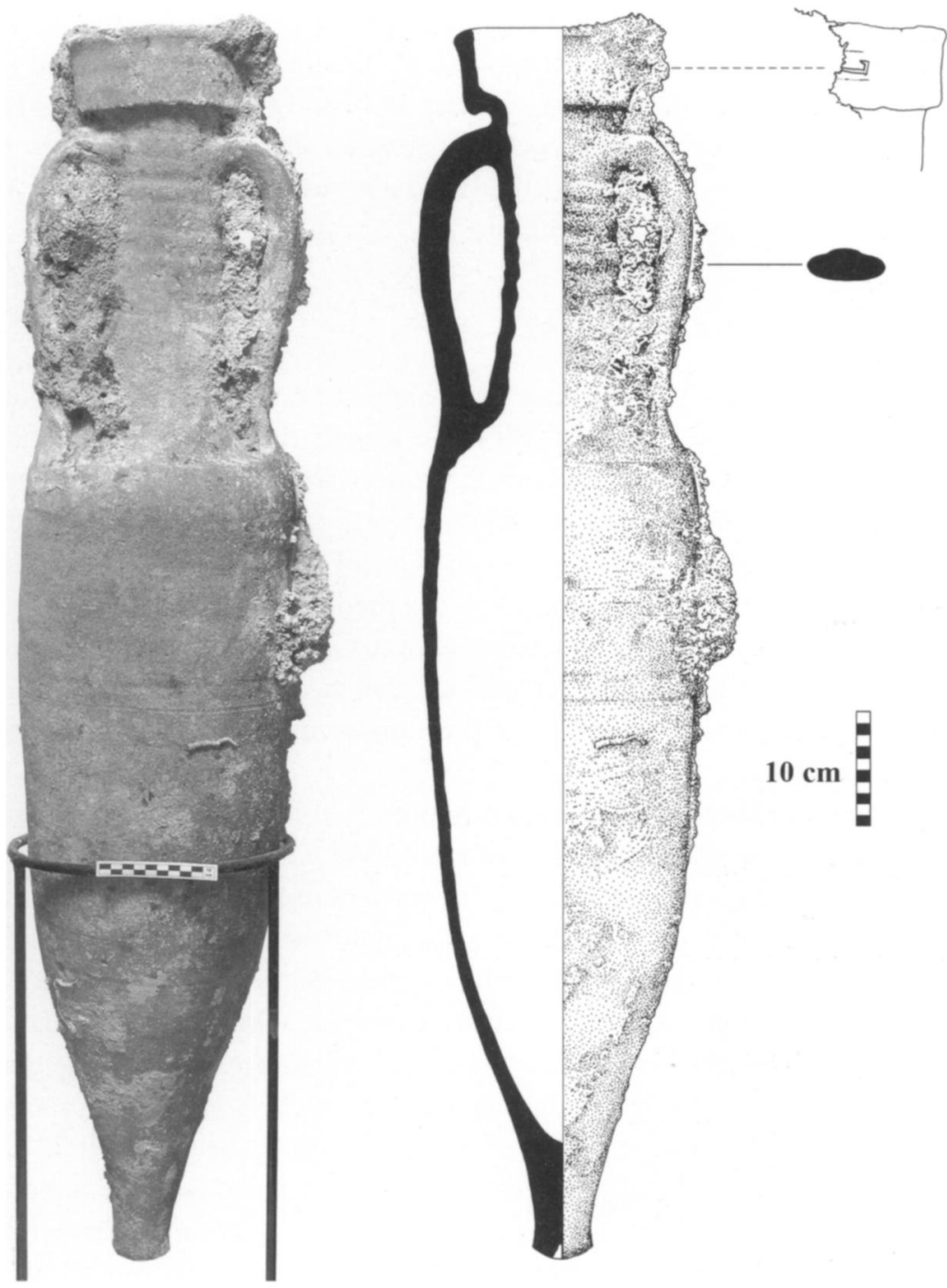

consisted of a scatter of approximately 40 amphoras, apparently all of the same type, lying very close to shore at the foot of a steep, rocky slope-a difficult environment for robotic survey and ship operations. Landslides had disturbed the site, breaking amphoras and partially obscuring them under rocks and sediment. The visible artifacts were heavily encrusted with marine growth and posidonia grass.

Because this site was shallow enough to achieve DVL bottom lock from the surface while the AUV was also receiving a GPS position fix, it was not necessary to deploy the LBL transponders. The team's divers reconnoitered the site and recovered a single Dressel 1C (Will Type 5) amphora with an incuse stamp on the rim (Fig. 4). This amphora type indicates a much earlier, Hellenistic, date for the wreck than expected, placing it in the late 2 nd/early 1 st century в.c. ${ }^{22}$ We then deployed the AUV. During a two-hour mission, the vehicle followed the depth contours along headings parallel to the underwater slope. The AUV collected the same types of data as during previous missions, including more than 2,000 
images of the debris field and surrounding seafloor. These images were later assembled into photomosaic strips (Fig. 5). While the robot surveyed the site, divers collected video footage of the AUV and amphora scatter. After recovering the vehicle, we discovered sea water intrusion in some of the AUV components. As this was the last day of our allotted ship time, we concluded AUV operations off Chios.

\section{Digital Image Mapping}

While GPS allows surface and air vehicles to track their global position to within a few meters, GPS radio signals do not penetrate under water. ${ }^{23}$ Therefore, typical methods for underwater navigation usually rely upon beacon-based navigation networks such as long baseline to offer bounded error position measurements. Use of this method comes at an expense, however, because it requires the predeployment and calibration of the beacon network as described above. Conversely, although deadreckoning-based navigation technologies such as DVL do not require a predeployed infrastructure, their position accuracy decreases with the distance traveled.

To combat these navigational limitations (i.e., infrastructure-based and unbounded error growth), team members at WHOI have been developing a camera-based navigation system. This system uses the vehicle-collected imagery of the seafloor to extract measurements of vehicle motion for fusion with the onboard dead-reckoning data in order to produce a boundederror navigation measurement. ${ }^{24}$ In essence, the AUV builds a digital map of the seafloor by registering overlapping digital-still images (both along-track and across-track imagery). Images that are successfully registered produce a relative measurement of both the vehicle's attitude (heading, pitch, and roll) and translational $(x, y, z)$ displacement. When fused with the onboard navigational data from the DVL, the result is a navigation system whose error is commensurate or much better than long baseline, but which is free of external infrastructure such as LBL transponders. The significant advantage of this navigation paradigm is that the AUV can be more easily deployed for exploratory surveys to investigate target shipwreck sites without having to invest significant ship time to deploy an acoustic beacon network for precision navigation. In layman's terms, these algorithms allow the AUV to navigate much like a human does, by navigating visually with respect to the seafloor environment.

An important and useful by-product of this navigation methodology is that the overlapping registered imagery can be used to construct an optically generated bathymetric map. This map can then be used to construct a quantitatively accurate three-dimensional photomosaic by back-projecting the imagery over the optical bathymetric map. Figure 6 displays the result of applying this technology to the Chios wreck A site. In particular, Figures 6:a and 6:b show the optically derived bathymetric map for a $15 \times$ $45 \mathrm{~m}$ swath centered overtop the wreck site. Figure 6:a shows the raw

23. Kinsey, Eustice, and Whitcomb, forthcoming.
24. Eustice, Pizarro, and Singh 2004; Eustice et al. 2006.

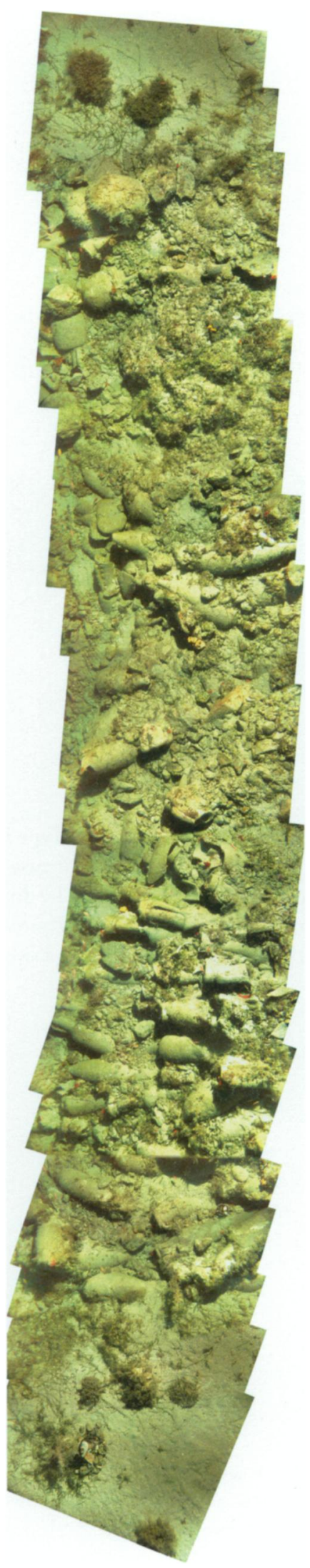




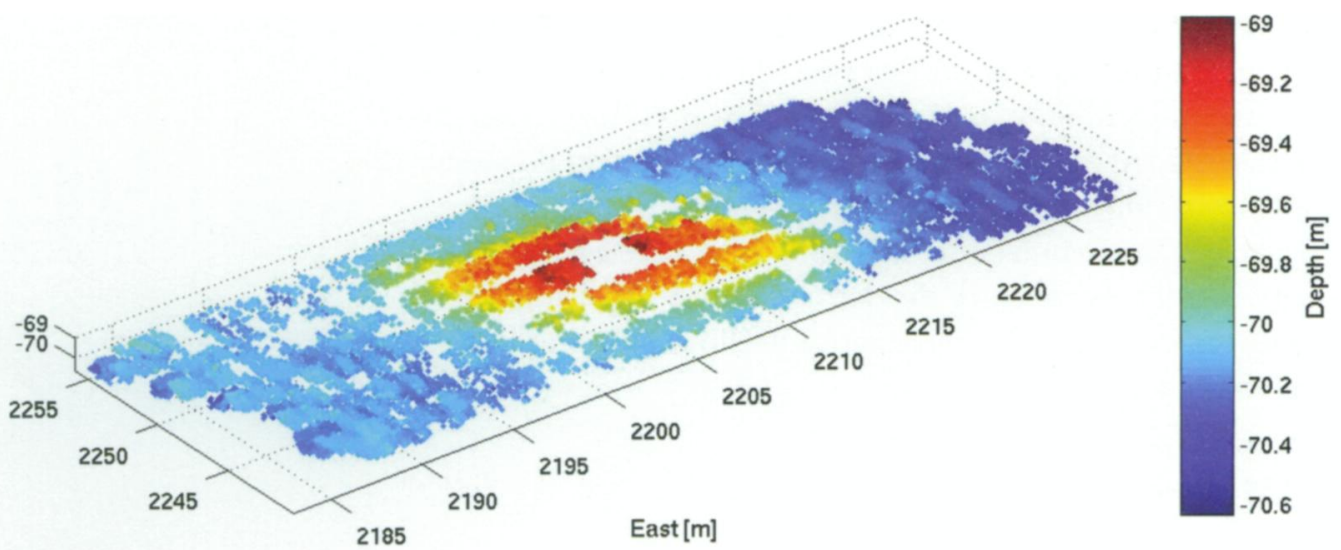

North [m]

a

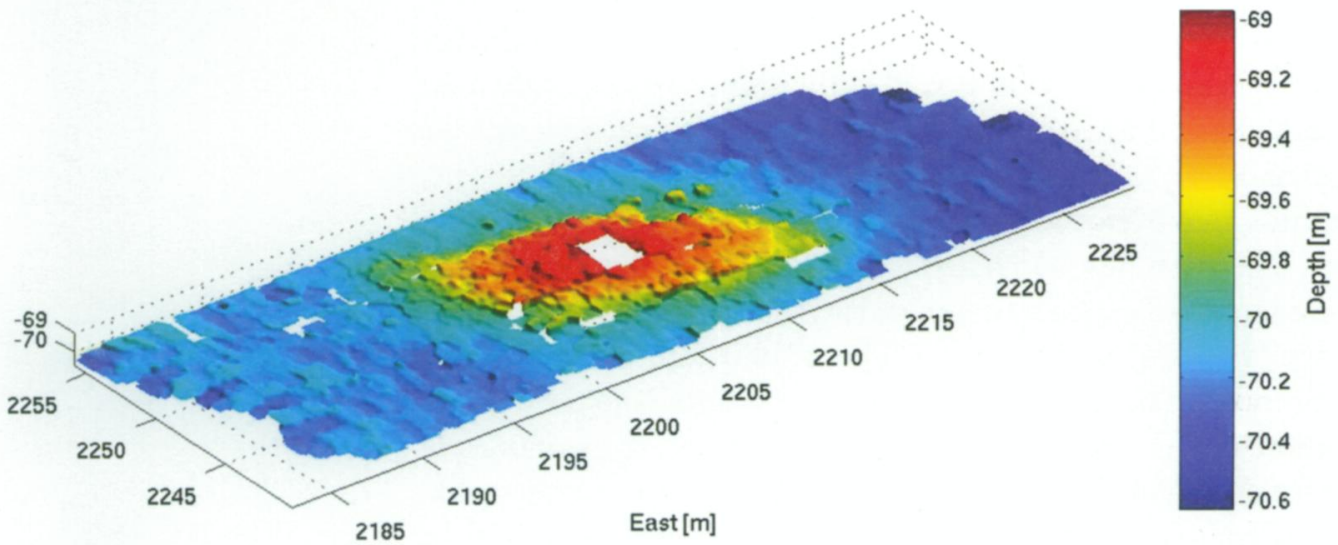

North $[\mathrm{m}]$

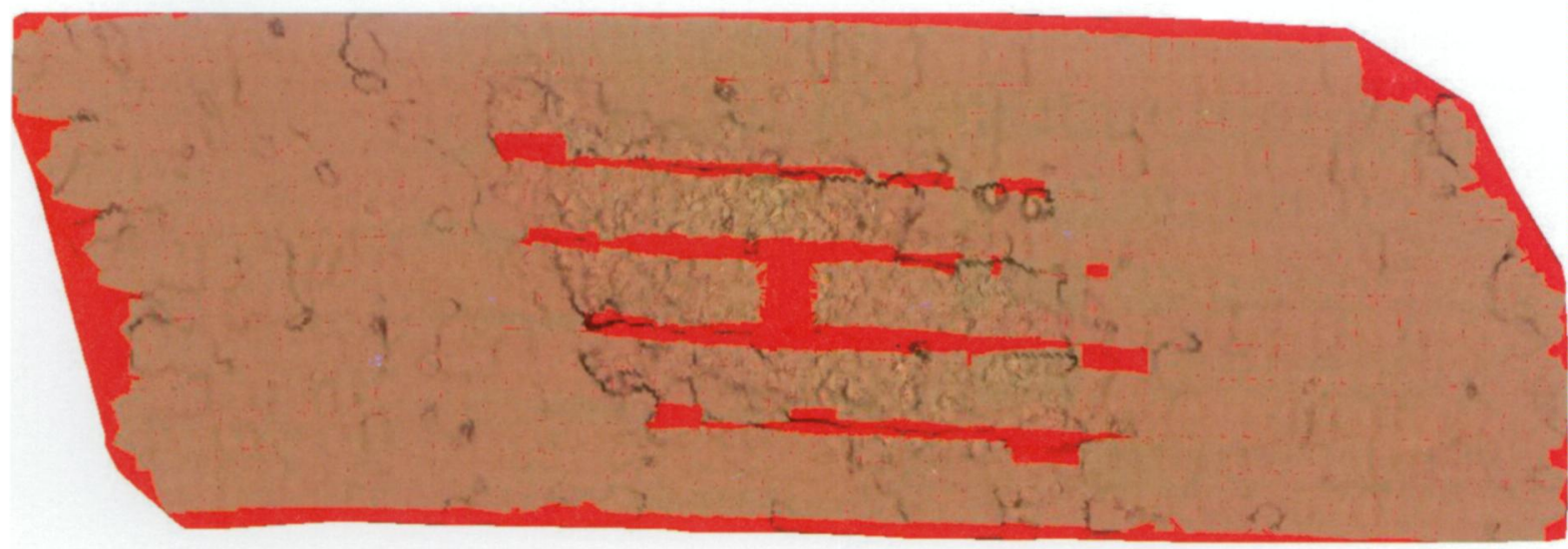

c

Figure 5 (opposite). Photomosaic strip of Hellenistic Chios wreck B near Lithi. B. P. Foley and Deep Submergence Laboratory, Woods Hole Oceanographic Institution
Figure 6 (above). Chios wreck A site: (a) Raw three-dimensional triangulated point cloud of optically derived bathymetry; (b) three-dimensional bathymetric map gridded at $5 \mathrm{~cm}$; (c) quantitatively accurate threedimensional photomosaic obtained by back-projecting digital imagery onto the gridded surface shown in (b). R. M. Eustice 
three-dimensional triangulated point cloud, while Figure 6:b displays a bathymetric map gridded at $5 \mathrm{~cm}$. Figure 6:c displays a quantitatively accurate three-dimensional photomosaic obtained by back-projecting the imagery onto the gridded surface. It should be emphasized that this result is fully automatic and metrically quantitative. In other words, measurements of object size and geometric relationships can be derived. While this technology is still very much in the active research stage, its current and future value for in-situ, rapid, quantitative documentation of marine archaeological sites cannot be overstated.

\section{Acoustic Mapping}

Multibeam sonar systems collect bathymetric data in a fan-shaped swath that is wide in the across-track direction and narrow in the along-track direction. These sonar systems are capable of providing dense data sets of bathymetric soundings that can be used to quantify the fine-scale characteristics of objects on the seafloor, as well as the seafloor itself. Bathymetric maps are generated by merging these sonar data with high-precision navigational data. ${ }^{25}$

There are a number of instrument-specific variables that affect the resolution of a multibeam sonar system, including sound frequency, beam pattern of the sonar as dictated by the transducer design, seafloor roughness, and the range (distance) to the bottom. The swath width of a multibeam system is a function of the angular sector of the transducer and the distance from the seafloor. The size of the acoustic footprint on the seafloor can greatly affect the resolution of the final map, as a large acoustic footprint over fine-scale complex seafloor terrain will not resolve the details of the seafloor, but will reveal broader bathymetric patterns. The acoustic footprint becomes larger with increasing distance from the seafloor. As a result, the acoustic footprint is smaller near the center of the swath and increases toward the edges of the swath. Similarly, the acoustic footprint increases with increased vehicle altitude.

Additional variables that affect the resolution of the final map are dependent on data-acquisition protocols. For example, the spatial density of bathymetric soundings is dependent on ping rate, vehicle speed, and vehicle altitude. While along-track data density is primarily dependent on survey speed and ping rate, across-track data density is dependent on characteristics of the multibeam system (e.g., beam width) and distance from the seafloor.

Multibeam sonar data collected during the Chios survey were gridded at $5 \mathrm{~cm}$ resolution (Fig. 7). This resolution is sufficient to reveal the detailed characteristics of the wreckage and the surrounding seafloor. There is no sign of a debris trail around wreck A. The wreck itself is bathymetrically complex; but even in the initial sonar plots, individual amphoras spatially isolated (horizontally or vertically) from the wreckage could be identified. With substantial post-processing of the sonar data, individual artifacts within the amphora mound can be discerned (Fig. 7, inset).

25. See Roman and Singh 2007. 


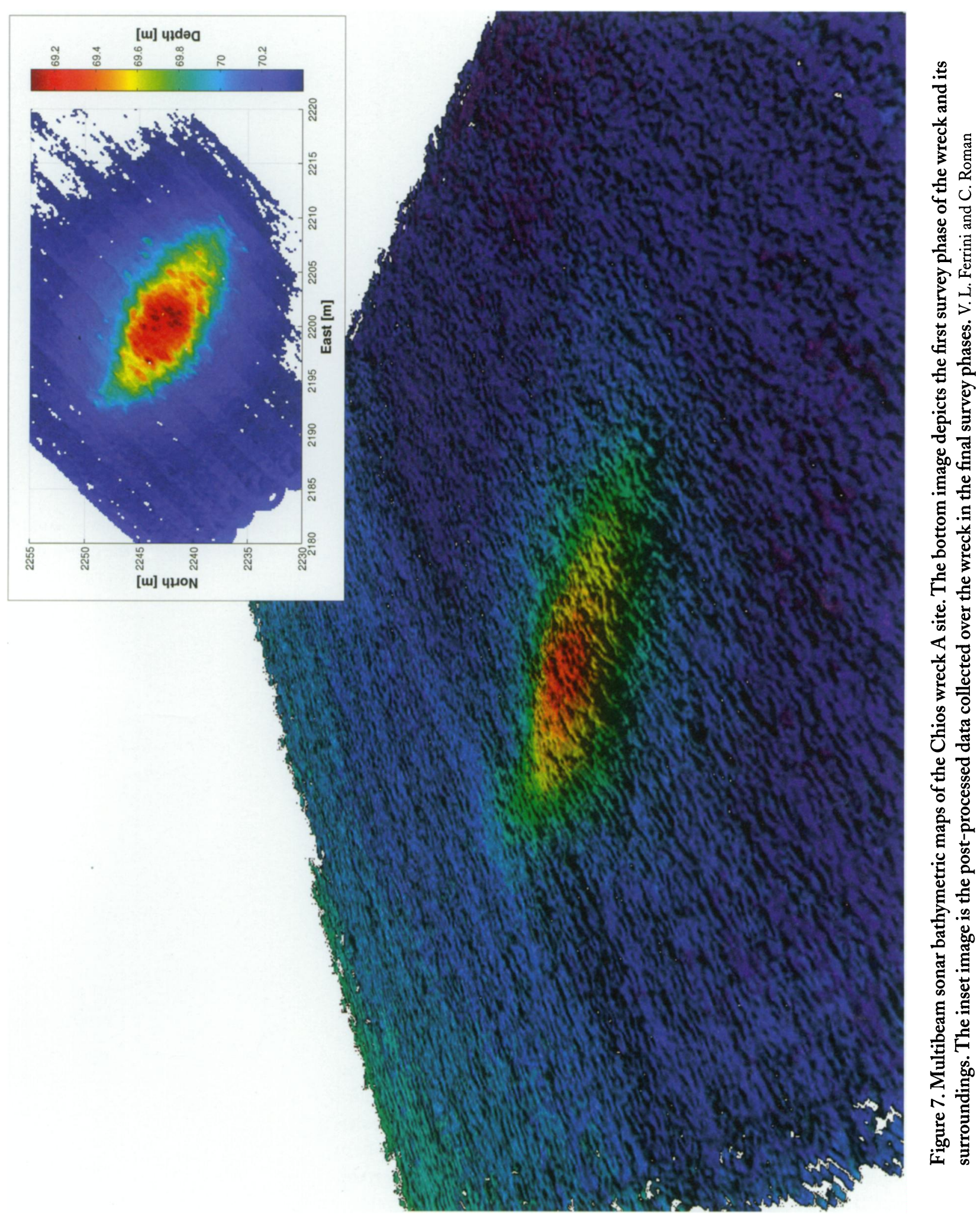




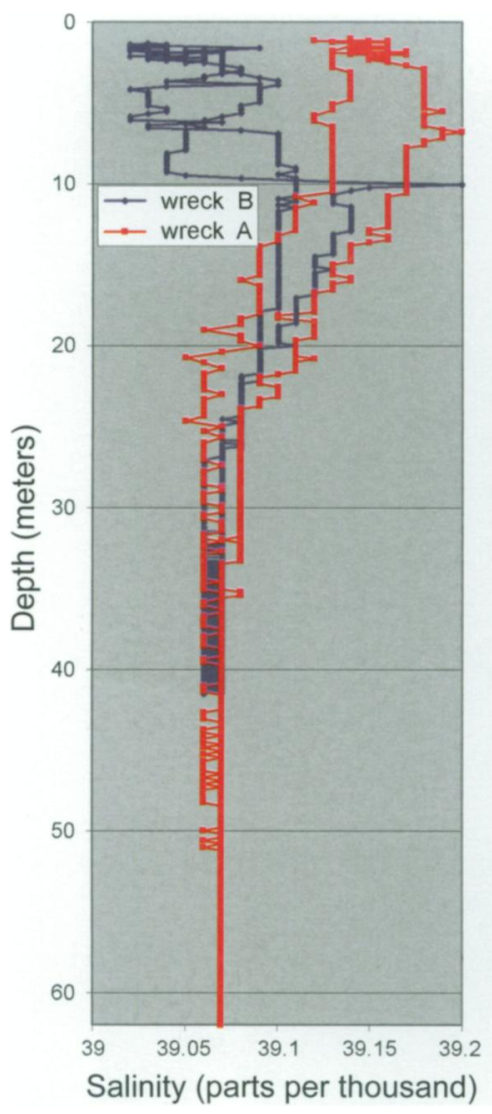

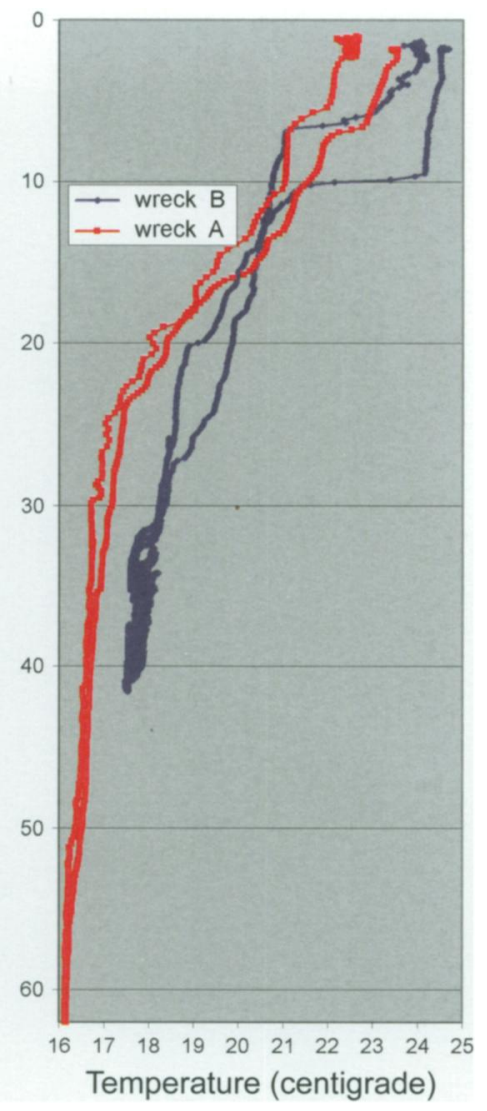

\section{ENVIRONMENTAL CONTEXT AND IMPLICATIONS FOR PRESERVATION}

During the Chios AUV surveys, in-situ chemical parameters were measured at both shipwreck sites using a suite of onboard sensors. The chemical parameters included salinity, temperature, chlorophyll, CDOM, and aromatic hydrocarbons. These parameters are useful in determining the thermal and kinetic energy inputs and mixing of the water, as well as the levels of biological and anthropogenic activity at the sites. Although the two Chios wreck sites are of roughly comparable age, lie in close proximity, and both sit in relatively shallow water, the data show that they have significantly different patterns of environmental degradation.

Salinity and temperature measurements at the older Chios wreck A site indicate a continuous gradient of decreasing temperature and decreasing salinity as functions of depth. These parameters exhibit absolute homogeneity in the overlying $2.5 \mathrm{~m}$ altitude waters of the site, showing no discernible temperature variability (resolvable precision $=0.01^{\circ} \mathrm{C}$ ) and no variation in salinity (resolvable precision $=0.01 \%$ ) (Fig. 8 ). Along with the absence of any detectable benthic currents, this suggests that the waters at this depth have had sufficient time to mix to equilibrium. Although the Bora and Meltemi seasonal winds routinely reach extremely high velocities in this region, modeling of the bathymetric shape and fetch limit of this section of the Chios Strait predict that storm energy imparted into the water column would be dissipated before reaching this wreck site.
Figure 8. Salinity and temperature data plots comparing the physical environments of the two wreck sites off Chios. R. Camilli 

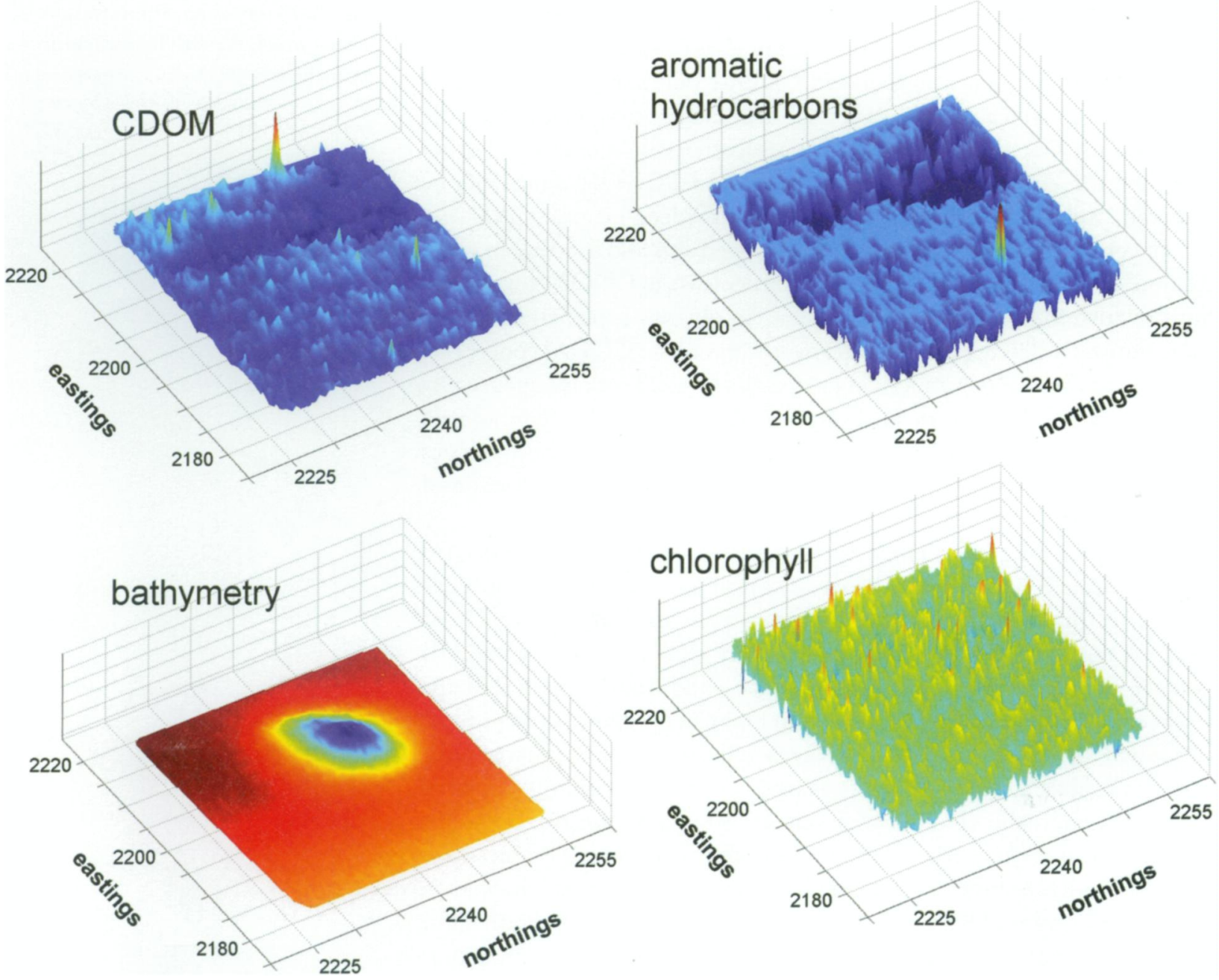

Figure 9. Chios wreck A survey, AUV dive 3: chemical parameters measured over the 4th-century B.c. wreck site. R. Camilli

26. Sakellariou et al. 2007, p. 371.

Optical and acoustic multibeam imagery of the area reveals a large contiguous amphora pile generally resembling an ellipse. The area surrounding Chios wreck A lacks the obvious furrow marks in the sediment characteristically made by the otter doors on trawl fishing nets, and there is no indication of a scour crater around the perimeter of the amphora mound. Overall, the data suggest that the wreck site has been undisturbed by storm events, benthic currents, or trawl fishing since its sinking.

The Chios wreck A site also appears to support limited photosynthetically derived biological activity. Optical imagery shows very little biological encrustation of wreck artifacts. In contrast, imagery from the Chios wreck B site clearly shows widespread encrustation, with sizable beds of posidonia grass around the artifacts. However, chlorophyll concentrations measured throughout the overlying water column at both sites were approximately $2.5 \mathrm{mg} / 1$, with little variability.

A step change in aromatic hydrocarbon concentrations occurs near the seafloor around Chios wreck A, increasing by a factor of three in the lowest $10 \mathrm{~m}$ of the water column (Fig. 9). The seafloor is generally composed of silty sediments exceeding $15 \mathrm{~m}$ in thickness. ${ }^{26}$ At the wreck site itself, aromatic hydrocarbon concentrations decrease. A plume of low 
concentration advects from a point source over the amphora mound, fanning out westward along a straight line from the mound. This lower concentration plume is also found in CDOM values at the site. Objects on this ancient wreck provide structural habitat attracting marine life; the hard ceramic material acts as a holdfast substrate for sponges and other invertebrates. The lower aromatic hydrocarbon and CDOM plume may be caused by waters advecting past benthic filter feeders (i.e., sponges).

In contrast, the Chios wreck $\mathrm{B}$ site averaged a sixfold decrease in water column aromatic hydrocarbons and a 16\% decrease in CDOM concentrations relative to the Chios wreck $\mathrm{A}$ site. An obvious explanation for the characteristic differences in aromatic hydrocarbon and CDOM concentrations is that the seafloor underlying the Chios wreck B site is largely comprised of rocky material instead of silty organic sediments. Furthermore, no anomalous depth-dependent aromatic and CDOM concentration changes were observed at the Chios wreck B site, nor was there any indication of localized variability in concentrations.

Further investigation of the environmental states at these sites is needed before definite conclusions can be reached as to the transformative mechanisms affecting them. Preliminary in-situ data suggest that Classical Chios wreck A may be better preserved than nearby Hellenistic Chios wreck B because of sediment chemistry, and because the basin's physical shape restricts kinetic energy inputs. The basin bathymetry appears to decouple Chios wreck $\mathrm{A}$ from wind and wave energy at the surface. The photographic and chemical data suggest that Chios wreck A may exist within a hypoxic basin. Although the chlorophyll levels are similar at the two sites, the evident lack of photosynthetic organisms and enriched organic concentrations within the sediments could enable a sustained microbial drawdown in dissolved oxygen. This sustained decrease in oxygen would greatly limit biological activity/encrustation of the wreck site, thereby attenuating biological degradation of organic materials and artifacts at the site.

\section{ARCHAEOLOGICAL EVIDENCE}

Multibeam sonar data show that the 4th-century B.c. Chios wreck A site forms an ellipse on the seafloor, with a maximum length of $21 \mathrm{~m}$, a width of $8 \mathrm{~m}$, and a vertical relief of $1.4 \mathrm{~m}$. The cargo remains are tightly contained within the dimensions of the wreck site; there is no debris trail around the wreck. The visible cargo remains consist of more than 350 amphoras of two types. The first type is attributed to Chios, with a generally oblong shape with a high straight neck, long vertical handles with high attachment points, conical body, carinated shoulder, and spiked base with a conical cup toe. The origin of the second amphora type is unknown. This amphora has a relatively short neck, short vertical handles, globular body, and a spiked base terminating in a knob toe.

Figure 10 represents a composite image assembled from hundreds of individual digital pictures, providing an otherwise impossible view of the wreck and its cargo. Of the observable Chian amphoras, 94 are intact, and 73 are broken. ${ }^{27}$ In the area containing the Chian amphoras, another 101 amphoras
Figure 10 (opposite). Photomosaic of Chios wreck $A$, with major features identified. B. P. Foley and Deep Submergence Laboratory, Woods Hole Oceanographic Institution

27. Many of the broken Chian amphoras have fractured cleanly at the shoulder or at the base of the neck. Dynamic computer modeling of that style conducted at WHOI confirms the observation that these are the weakest points of the shape. When subjected to external pressure or shock, the Chian amphora fractures along the seams at the shoulder or the base of the neck. 


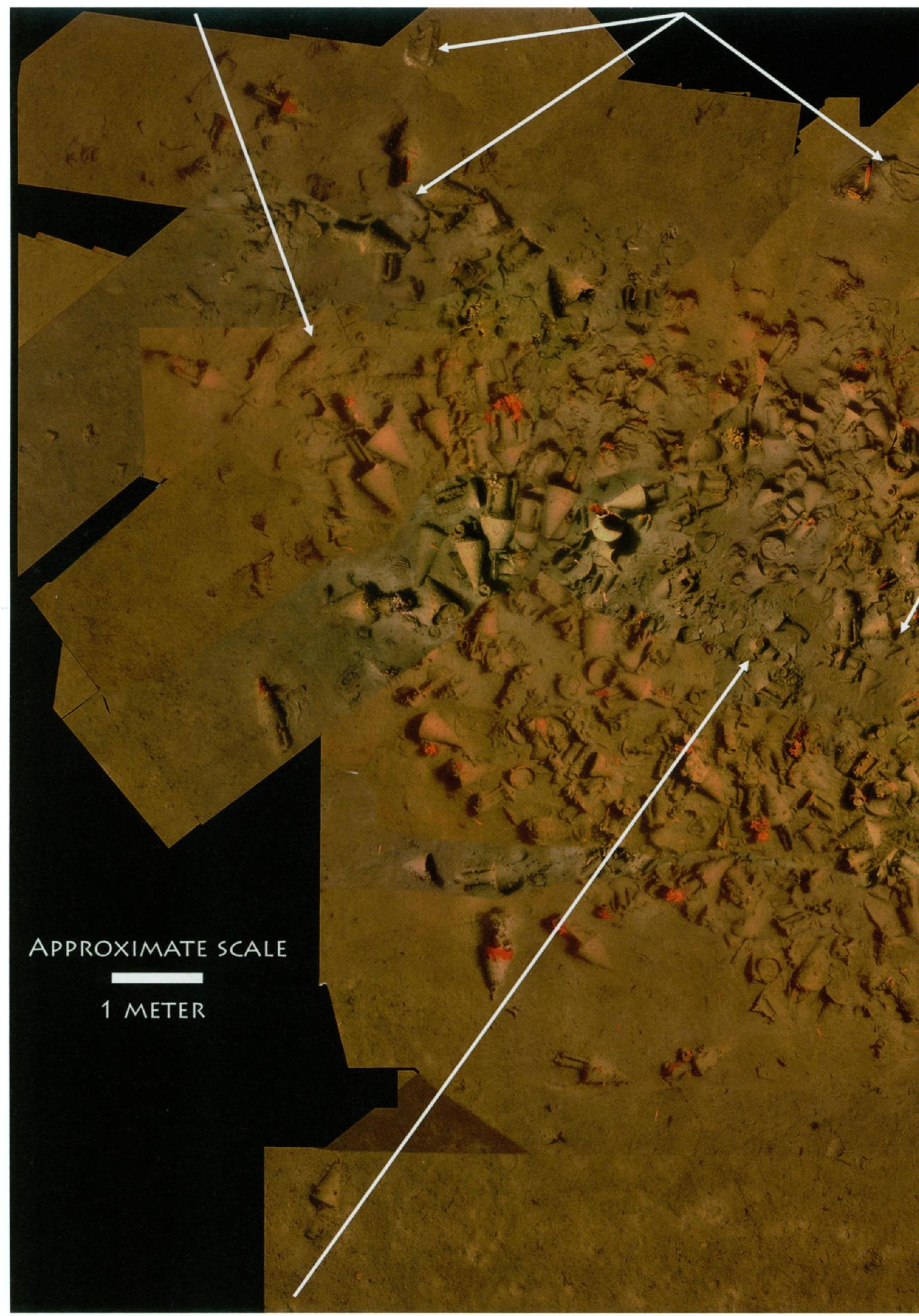

This content downloaded by the authorized user from 192.168.52.64 on Mon, 10 Dec 2012 15:05:17 PM All use subject to JSTOR Terms and Conditions 


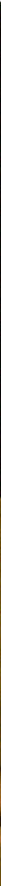

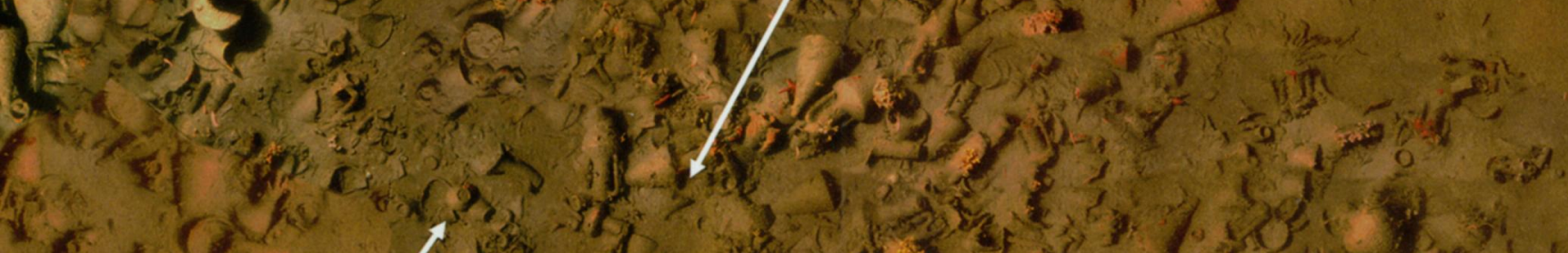
(1)

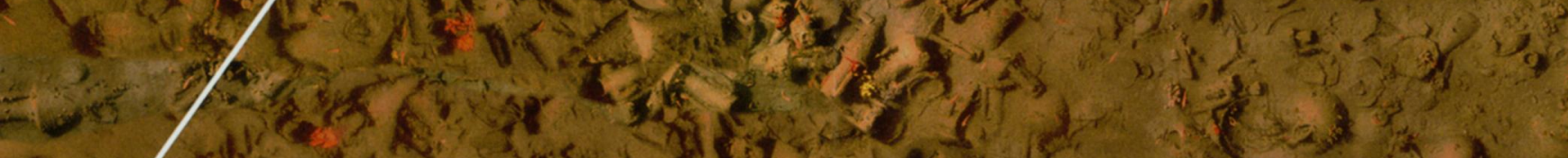

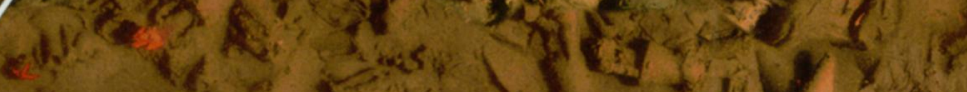

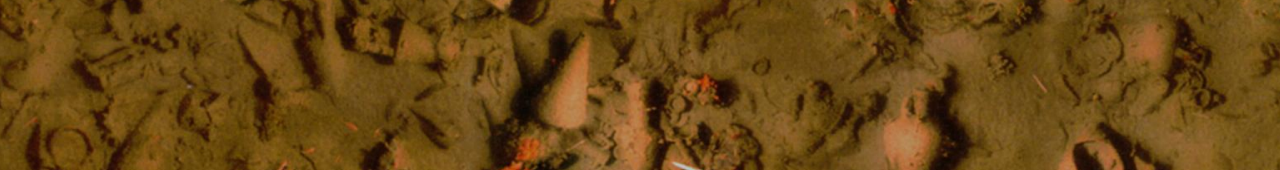

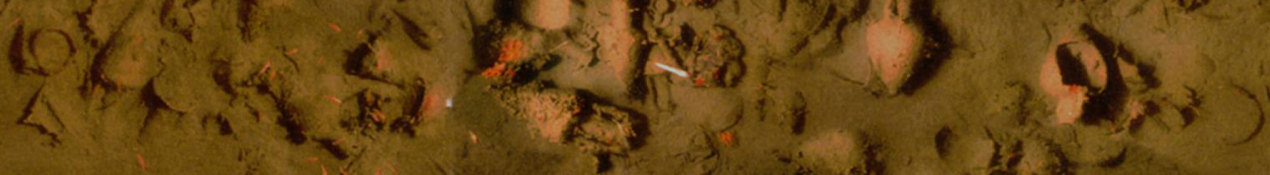

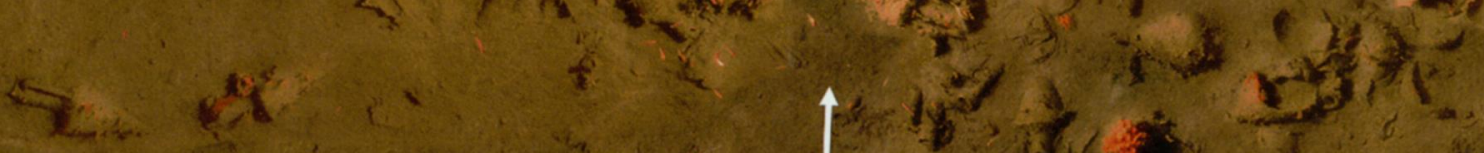
$x$

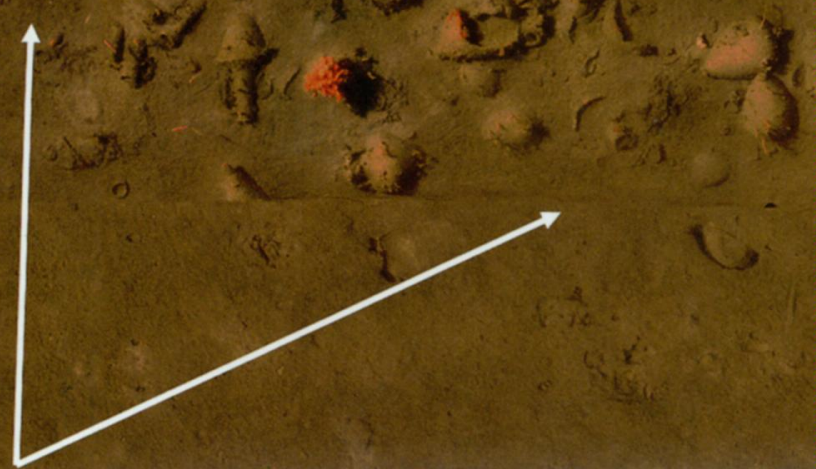




\section{Possible Thasian amphora toe}

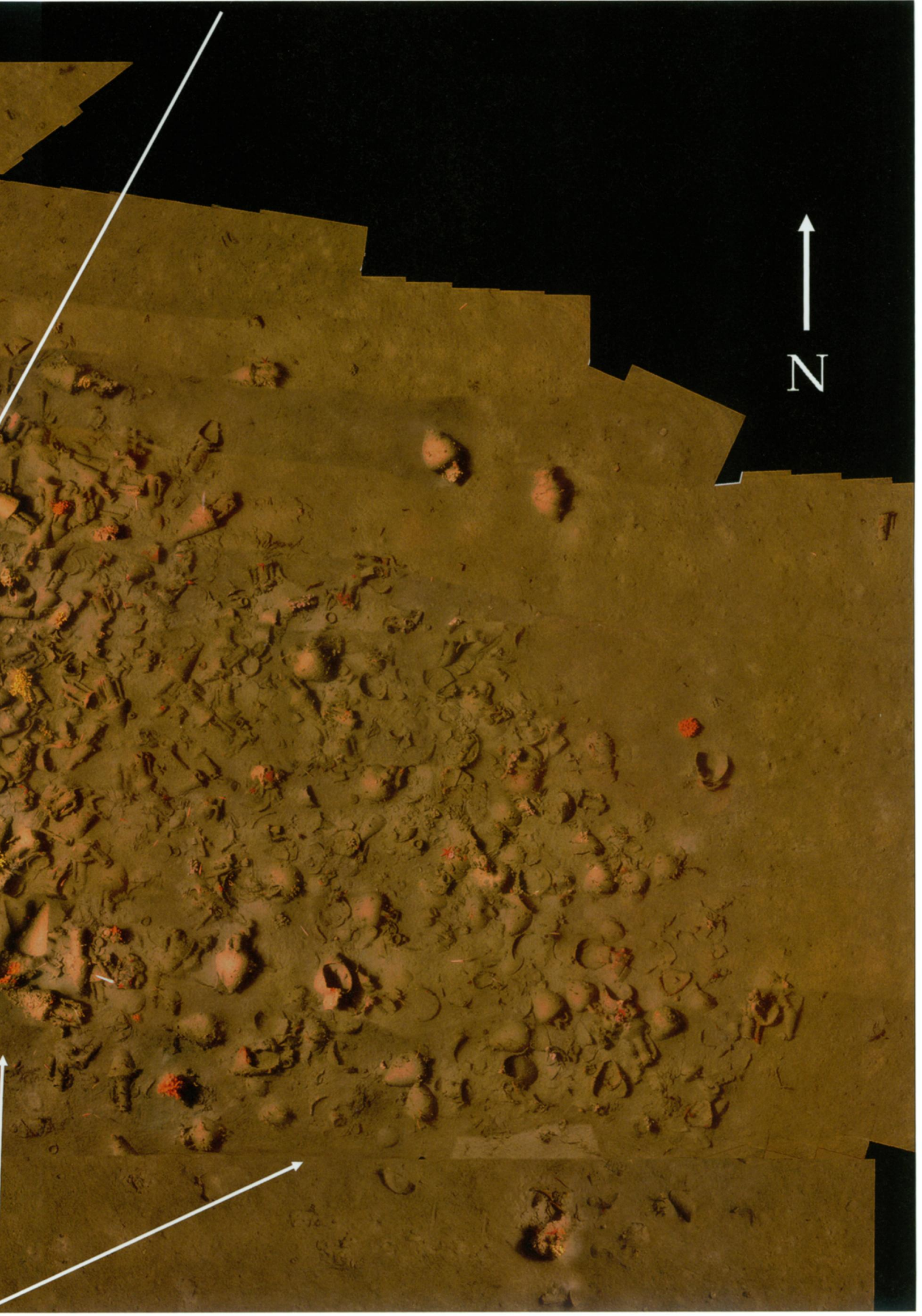

This content downloaded by the authorized user from 192.168.52.64 on Mon, 10 Dec 2012 15:05:17 PM All use subject to JSTOR Terms and Conditions 


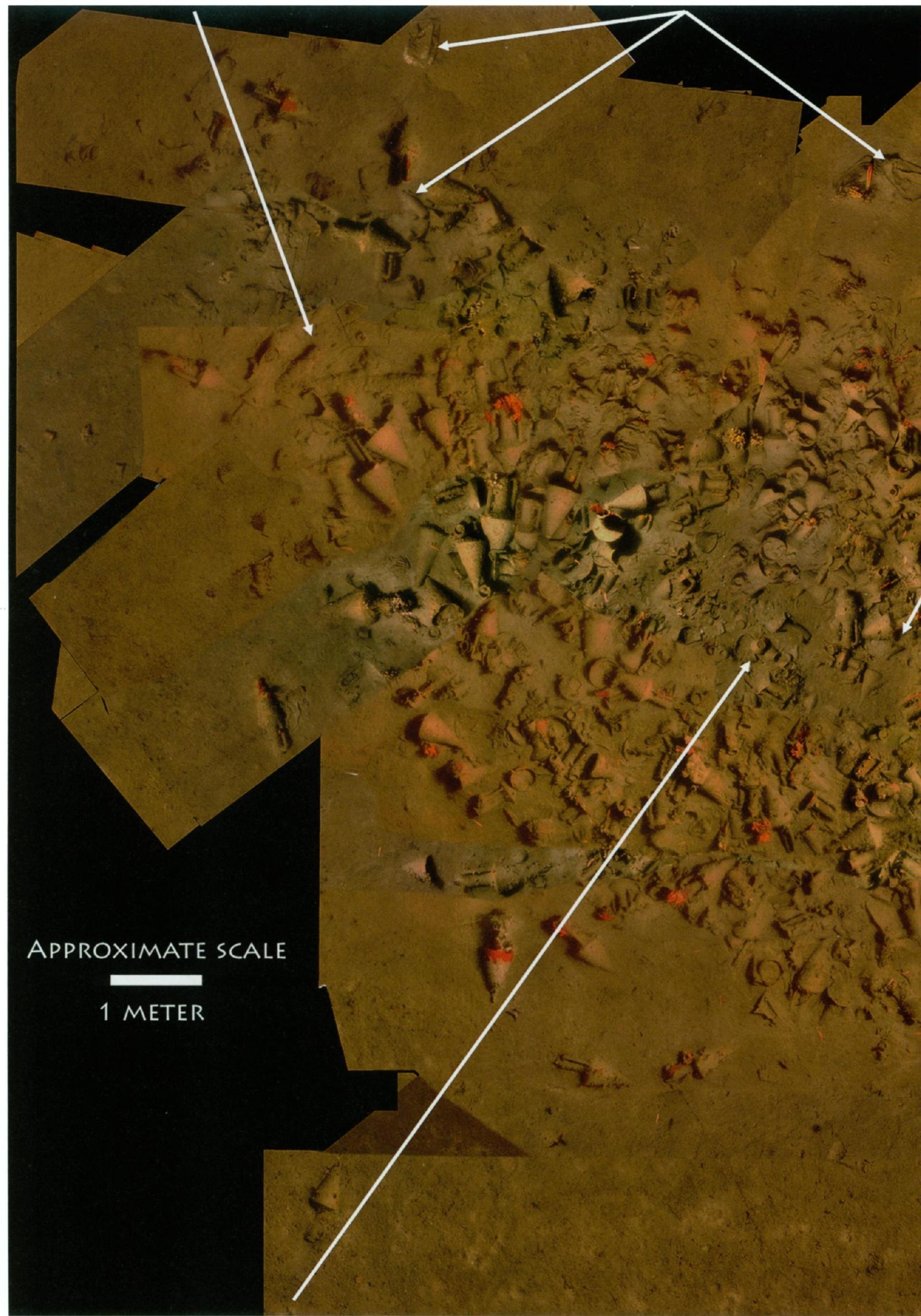




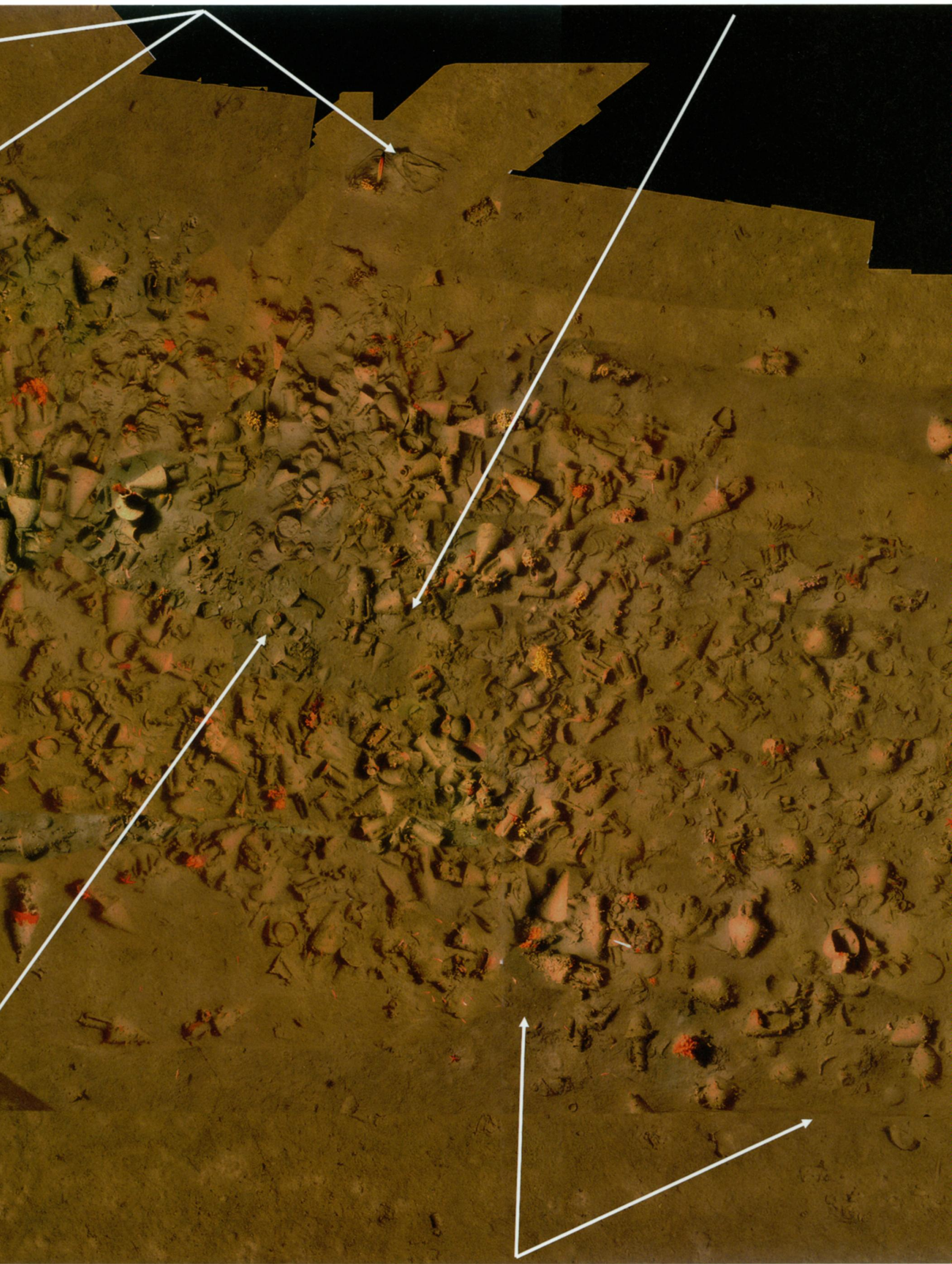


Figure 11. View of full-sized and smaller Chian amphoras on Chios wreck A, shown in situ, viewed from southeast. Sponges are growing on both amphoras, and modern trash (plastic cup) can be seen in left center of image. Photo Chios 2005 team
28. Docter 1990, p. 149.

29. Docter 1990, p. 149.

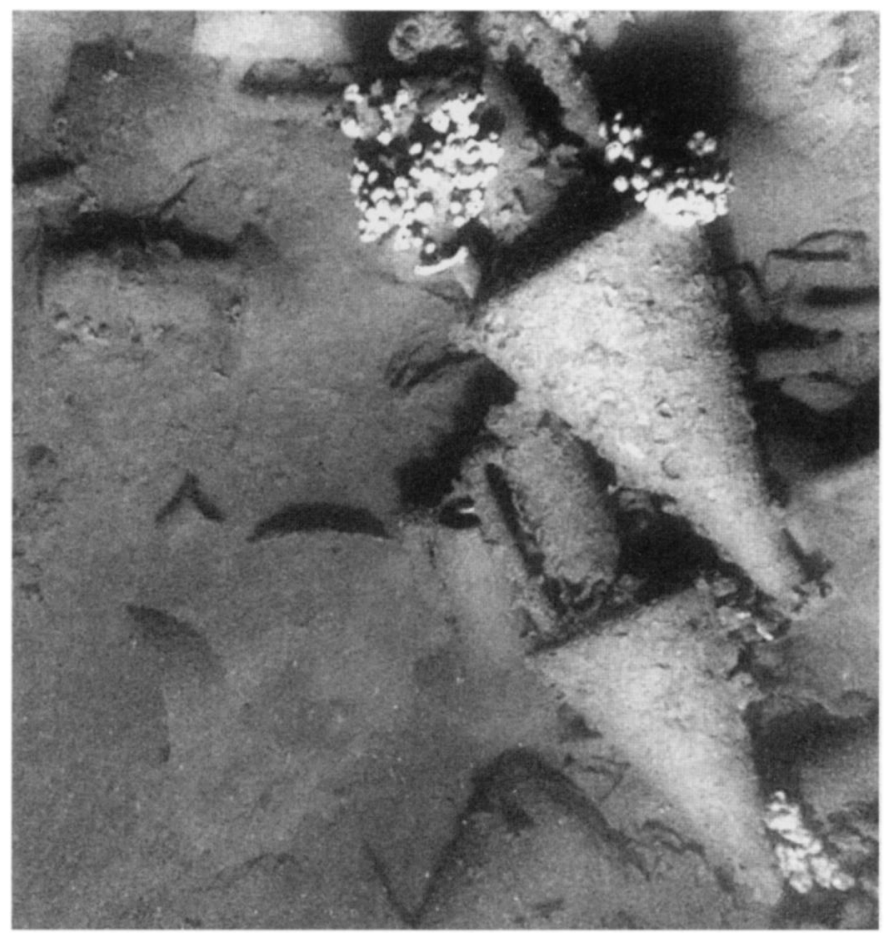

are visible. They appear to be Chian, as well, but are too covered in sediment to determine if they are intact or broken. The digital images show that the Chian amphoras have similar dimensions, with one exception (Fig. 11, lower right) that is somewhat smaller than the predominant type.

In 2004, HCMR and EUA scientists recovered from the site a wellpreserved Chian amphora, designated BE2004/4.1 (Fig. 12). The vessel is intact except for one missing handle, but traces of that handle's attachments remain on the neck and shoulder. The clay color is red (Munsell 2.5YR $5 / 6$ ), and the amphora's dimensions are overall height 0.915 , maximum diameter 0.340 , handle height 0.320 , toe height 0.070 , depth of recess in toe 0.040 , and neck inner diameter $0.087 \mathrm{~m}$. EUA archaeologists measured the volume of this amphora by filling the jar with water, according to accepted practice. ${ }^{28}$ The volume to the base of the neck is $19.0 \mathrm{l}$, and the total volume to the rim is 22.01 .

The second amphora type found at wreck $A$ is of an unattributed variety. There are 30 intact examples of this type discernible in the imagery, at least 12 that are broken, and many fragments representing an unknown number of additional amphoras. In 2004, HCMR and EUA recovered one amphora of this type, designated BE2004/4.4 (Fig. 13). The clay color is light red (Munsell 2.5YR 6/6), and the amphora dimensions are overall height 0.665 , maximum diameter 0.400 , handle height 0.145 , neck height 0.140 , and neck inner diameter $0.085 \mathrm{~m}$. The capacity of this amphora was also measured by filling it with water. ${ }^{29}$ The capacity at the base of the neck is 32.41 , and the total internal volume measured at the rim is 331 .

The digital images of Chios wreck $A$ show mouths of 37 more amphoras visible in the sediments, but it is impossible to determine their type or condition. They appear to be standing upright, and they may still be in 

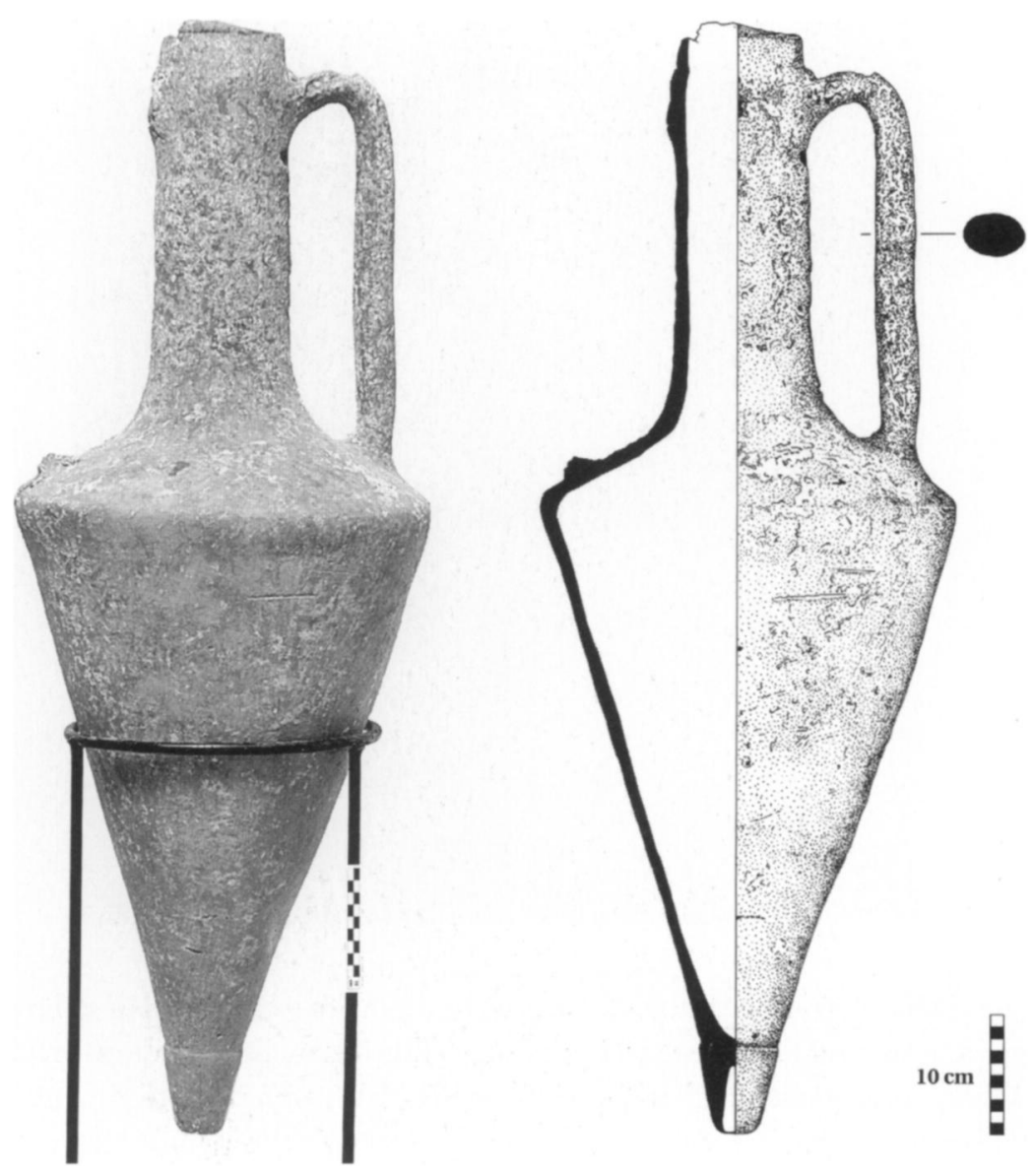

Figure 12. Chian amphora BE2004/4.1 recovered from Chios wreck $A$ by HCMR and EUA in 2004. Photo P. Vezirtis; drawing E. P. Oberlander
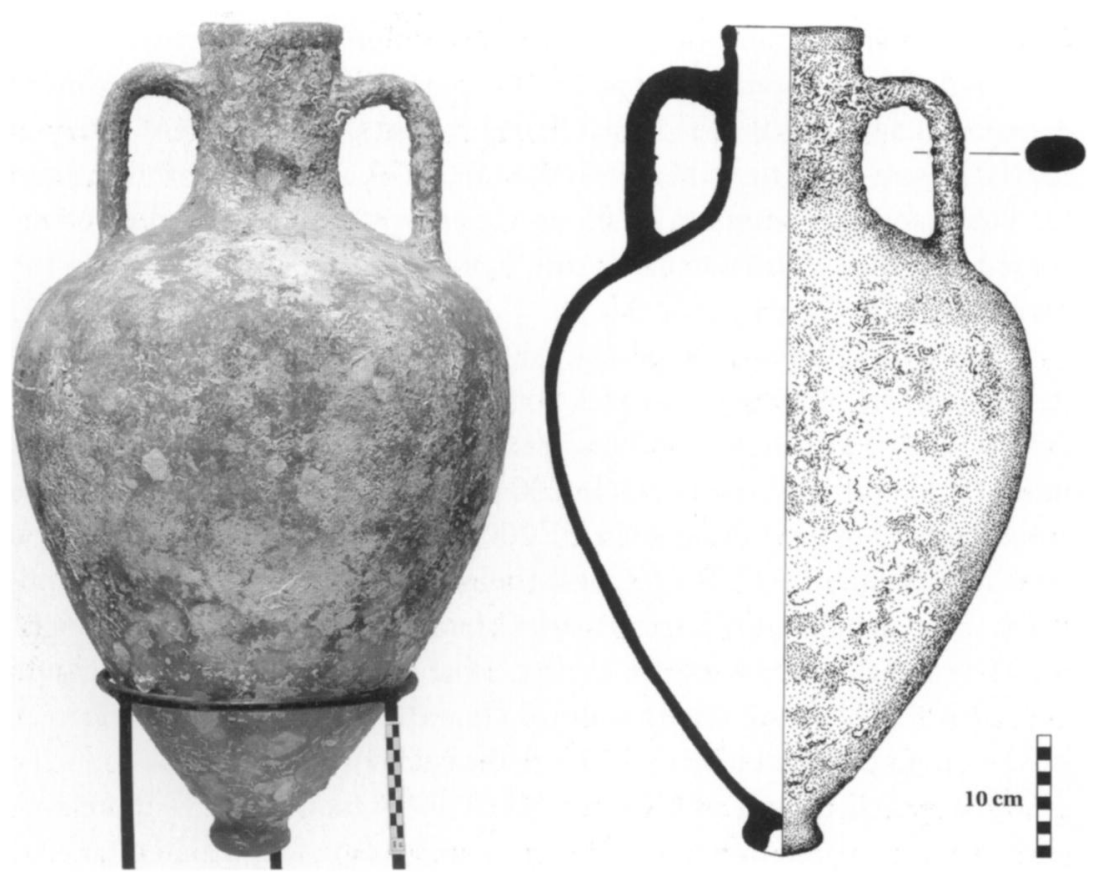

Figure 13. Unattributed amphora BE2004/4.4 recovered from Chios wreck $A$ by HCMR and EUA in 2004. Photo P. Vezirtis; drawing E. P. Oberlander 
Figure 14. Possible anchor at western end of Chios wreck $A$, alongside amphoras. Photo Chios 2005 team
30. Hadjidaki 1996, p. 574.

31. Casson 1995, pp. 254-256.

32. Monakhov and Rogov 1990, p. 144.

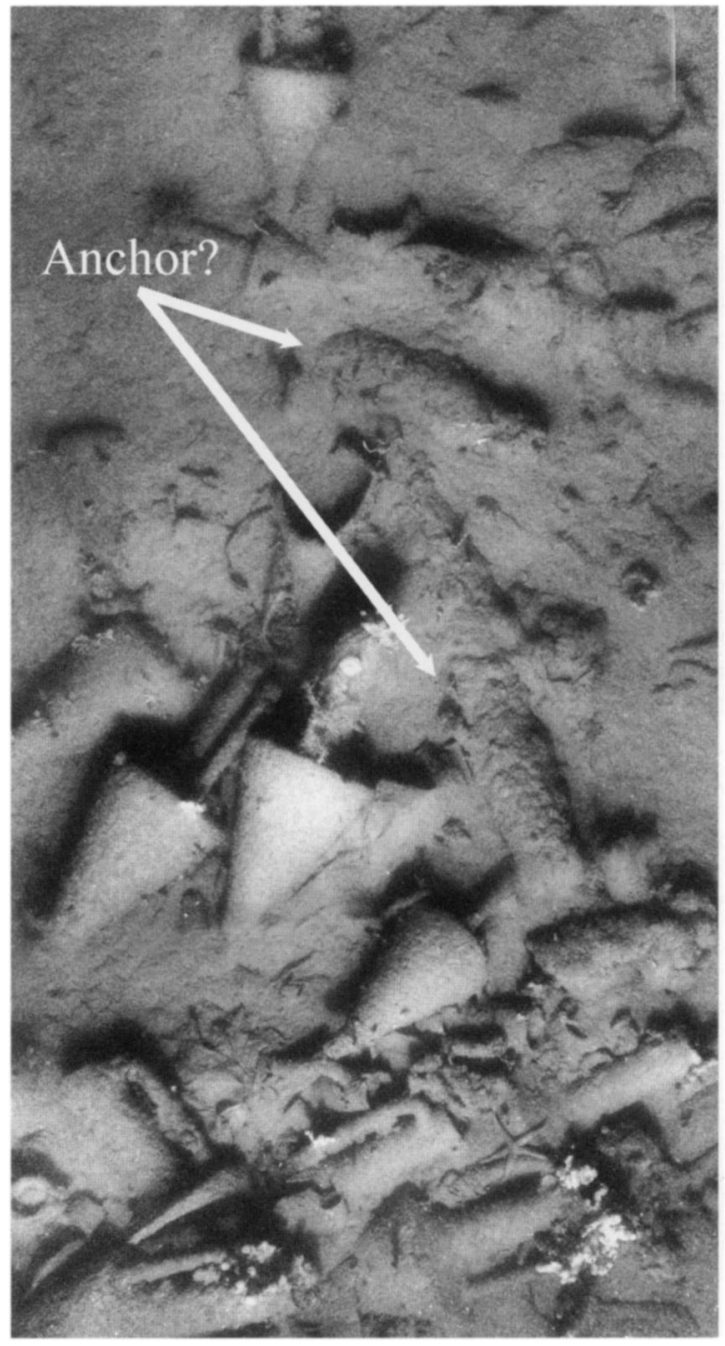

their original loading positions, possibly indicating that additional layers of amphoras may be buried in the sediments below the observable artifacts. By comparison, a 5th-century B.c. wreck excavated at Alonnesos contained four tiers of amphoras occupying $1.5 \mathrm{~m}$ of vertical relief. ${ }^{30}$

The extreme western end of Chios wreck A contains a feature that is suggestive of an anchor shank and arm (Fig. 14). This feature is less than $2 \mathrm{~m}$ long, however, and may be too small for ground tackle. ${ }^{31}$

The photomosaic (Fig. 10) reveals a small area (about $1.5 \mathrm{~m}^{2}$ ) of decreased amphora density along the centerline near the western end of the wreck. This might represent the location of the ship's mast. Nearby, the toe of one amphora of perhaps Thasian or northern Aegean type is evident (Fig. 15). ${ }^{32}$ This area also contains an assemblage of several small pots possibly used by the crew, or perhaps representing a secondary cargo consignment in addition to the amphora cargo.

A single example of a jug (designated BE2005/4) was recovered from Chios wreck A using the HCMR ROV in 2005 (Fig. 16). BE2005/4 is a plain-ware jug missing the rim, part of the neck, the handle or handles, 

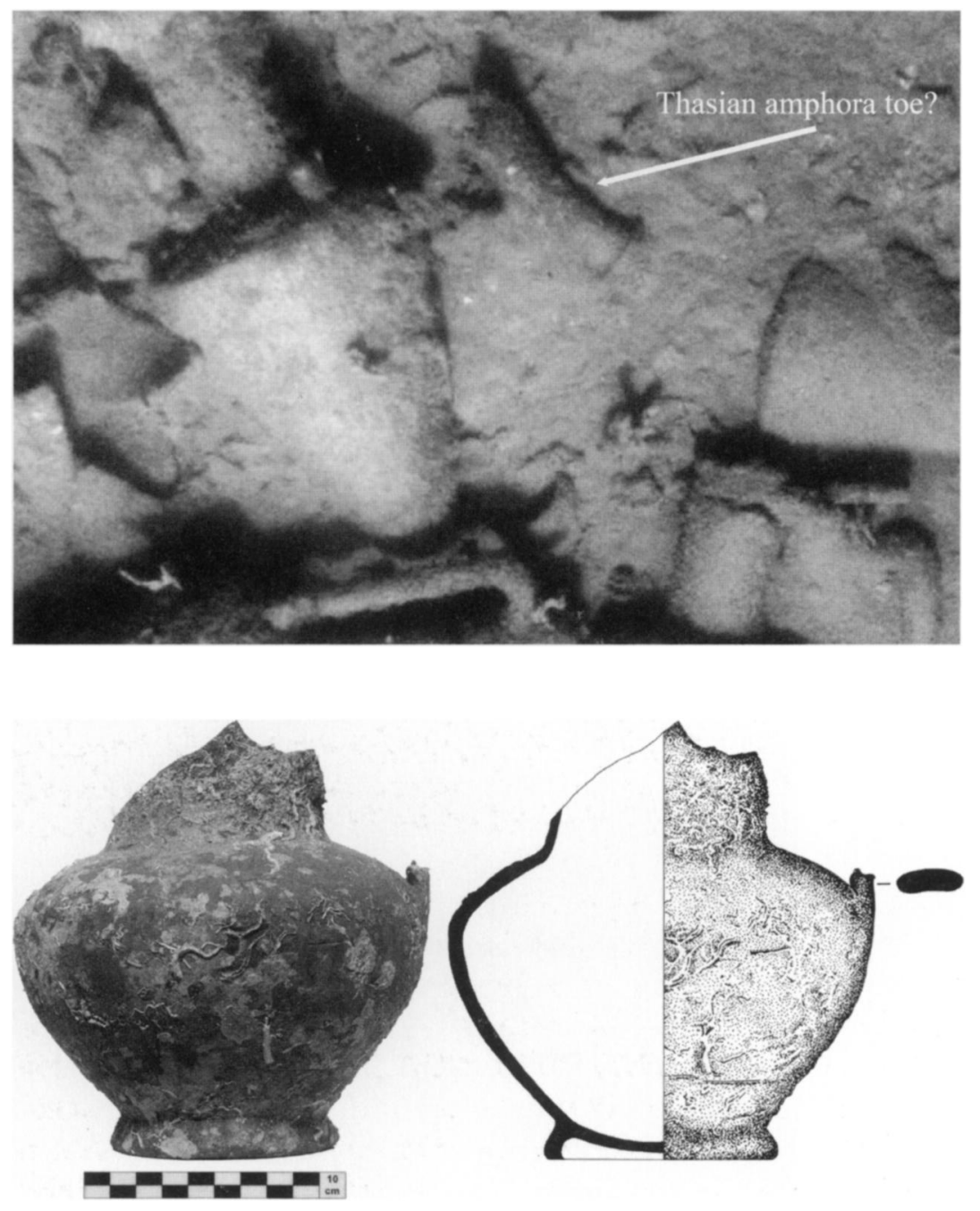

and part of the body. It has a compressed spherical/ovoid body and a ring base. The clay is reddish brown to dark reddish gray (Munsell 5YR 5/3), and the dimensions of the jug are overall height 0.175 , diameter 0.170 , and base diameter $0.095 \mathrm{~m}$. The inner surface was coated with a thin layer of earthlike material, which has not yet been analyzed. This jug is a plain wide-neck type with a slightly angular shoulder; the base of one handle is preserved. A close parallel of the vessel had been found earlier in the Chios harbor. ${ }^{33}$ The Chios wreck $A$ jug can be dated within the 4th century B.c. and placed stylistically between a type A jug of the Ephesos Tetragonos Agora (first half of 4th century B.c.) $)^{34}$ and a series of jugs from Rhodes (last quarter of 4 th century B.c.). ${ }^{35}$

33. This unpublished jug was retrieved in 1985 from the southern part of the Chios harbor along the inside of the southern mole during an illegal dredging operation that was halted by EUA. The jug initially was placed in the collection of the Chios Archaeolog- ical Museum (inv. 4063) and later in 1985 was moved to the Conservation Laboratory of EUA, where it was renumbered as $85 / 34$. The neck and rim are broken and the handle is missing, but the jug has the same shape as the jug from Chios wreck A. Its dimen-
Figure 15. Toe of an unidentified (possibly Thasian) amphora on Chios wreck A, located alongside Chian amphoras. Photo Chios 2005 team

Figure 16. Small jug BE2005/4 recovered from Chios wreck $A$ in 2005 by HCMR Super Acbilles ROV. Photo P. Vezirtis; drawing E. P. Oberlander

sions are max. p.H. 0.20, max. Diam. 0.18, base Diam. $0.09 \mathrm{~m}$.

34. Ephesos XIII.2, pp. 89-90, fig. 101, the first vessel to the left; see also p. 328 , and pl. 14, no. 95 .

35. Giannikouri, Patsiada, and Philimonos 2000, p. 75, pl. 23: $\beta$, no. П8181. 
TABLE 2. SHIPWRECKS ROUGHLY CONTEMPORARY WITH CHIOS WRECK A

\begin{tabular}{lcccl}
\hline Location of Shipwreck & Est. Date B.C. & Site Length (m) & Site Width (m) & Amphora Cargo \\
\hline Tektaş Burnu, western Turkey & $440-425$ & 12 & 4 & 200 \\
Alonessos, Sporades, Greece & 410 & 25 & 14 & 1,000 (top layer); 4,000 total? \\
Porticello, Messina, Sicily & 390 & 16 & $?$ & looted \\
El Sec, Mallorca, Spain & 375 & similar to Kyrenia & similar to Kyrenia & total 475, but looted \\
Chios wreck A & $350-330$ & 21 & 8 & 350 (top layer) \\
Kyrenia, northern Cyprus & $295-285^{*}$ & 14 & 4.5 & total 400+ \\
Serçe Liman, southwestern Turkey & 280 & 11 & 9 & total 600+ \\
\hline
\end{tabular}

*'The Kyrenia wreck was originally published as dating to ca. 325 в.c.; see Katzev 1972.

Sources: Carlson 2003, 2004; Hadjidaki 1996; Lawall 1998a; Arribas et al. 1987; Susan Katzev, pers. comm.; Pulak and Townsend 1987. Note: Two other Classical wrecks are not included in this table, either because the cargo was not primarily composed of amphoras or a complete survey was not performed. The Ma'agan Mikhael wreck (ca. 410-390 в.c.) off Israel carried building materials rather than an amphora cargo; see Linder, Kahanov, and Black 2003. The Phagrou wreck in Greece (ca. 450 в.c.) carried amphoras, but awaits survey.

In addition to the objects carried on the vessel when it sank, the wreck has trapped modern trash, including plastic bags, cups, and water bottles (see Figs. 10 and 11, above). This material has been carried onto the site by benthic currents - a phenomenon long observed on other deepwater shipwreck sites. Ancient debris also travels across the seafloor; anachronistic artifacts encountered in the supposedly closed context of a wreck site may be explained by this mechanism. ${ }^{36}$

In comparison to other roughly contemporary shipwrecks, Chios wreck $A$ is larger than all but the Alonnesos vessel (Table 2). The number of amphoras visible on wreck A's top layer is evidence that it was a relatively large ship for its time, but further investigation is necessary to determine the total number of amphoras contained within the $1.4 \mathrm{~m}$ tumulus.

As described above, the Chian amphoras on the wreck site are straightnecked with a conical cup toe (see Fig. 12). Intact examples and sherds of similar jars have been excavated from 4th-century B.c. contexts in the northern Black Sea. Chian "dunce cap" toes appear in a stratum dating to the middle of the 4th century в.c. from the Belozerskoe settlement near the mouth of the Dnieper River, Ukraine. ${ }^{37}$ Complete examples were excavated from child burials in the necropolis tumulus at Panskoe I in westernmost Crimea, dating to the third quarter of the 4 th century в.c. ${ }^{38}$ Closer to Chios, sherds of similar cup-toed amphoras have been studied at Ilion. They were excavated from strata dating no later than 330 в.c. ${ }^{39}$ The Chian amphoras contained within Chios wreck A conform closely to the mid-century form. An exact parallel has also been found in the Athenian Agora: Chian amphora P 25947. ${ }^{40}$ This amphora was excavated

36. Parker 1981, p. 309. Investigations of deepwater sites reveal that the deep seafloor is more dynamic than Parker suspected, and ancient and modern artifacts may move greater distances than previously imagined; see Foley and Ballard 2004.

37. Bylkova 1996, 2005, pp. 221, 236; Lawall 2005, pp. 43, 45.
38. Monakhov and Rogov 1990, p. 138. Hind (1992-1993, p. 92) reports Chian amphoras imported into 5 th- and 4th-century B.c. Nikonian and Ordessos, in modern-day Ukraine. 205.

39. Lawall 2002, pp. 202, 204-

40. Grace 1979, fig. 46. 
from fill in deposit F 17:3 that is dated to the second half of the 4th century B.c. ${ }^{41}$ Taking all of this into account, it seems most likely that the ship sank sometime between 350 and 330 B.C., and certainly no later than 315 B.c.

Earlier Chian amphoras differed significantly in style and capacity from the mid-4th-century form. ${ }^{42}$ From the end of the 6th century to the middle of the 5th century B.C., Chian amphoras featured a distinctive bulbous neck, and their internal volume averaged seven Chian choes. In the later 5 th century, the capacity of this Chian amphora style might have increased to eight Chian choes, equivalent to seven Attic choes. Then the new form of straight-necked Chian amphoras appeared. Production of the bulgingneck style might have overlapped with the new style until ca. 425 B.c., when the bulging-neck amphora was fully superseded by the straightnecked style. ${ }^{43}$ The straight-necked style had a capacity of eight Chian choes, equivalent to seven Attic choes. ${ }^{44}$ The initial change in capacity and subsequent change in style reflected in the bulbous-to-straight neck transition might have resulted from the Athenian Standards Decree, under which the Chian producers conformed to the Attic standard. Among the scholars who point to this decree as the reason for the change in measure, there is disagreement about the date of its issuance. Some scholars posit a date of 448-446 B.C., ${ }^{45}$ but more recently, others have convincingly argued for a date around 424 B.c. ${ }^{46}$

Political changes can be reflected in the objects produced by a society, and the history of Chian coinage provides good examples of this phenomenon. Chios minted coins on its own standard from 525 в.c. until the Athenian Standards Decree, when a break occurred in coin production. In 412 B.c. the Chians revolted against the Athenian League, and they resumed minting coins based on their own standard. ${ }^{47}$ Relations between Athens and Chios warmed for a period with a new Second Athenian League alliance in $379 / 8,{ }^{48}$ but tensions soon built again, erupting with the Social War of 358/7-355/4 в.c. At this point, Athens attacked Chios and possibly fomented an insurrection of the sizable slave population on the island. Ultimately, Persian intervention resulted in Chian independence from Athens. ${ }^{49}$ Throughout the politically tumultuous period following the 412 в.c. revolt, Chian coins conformed to the island's own standard. ${ }^{50}$

Changes in Chian amphora measures might amplify the trends evident in the island's coinage standards. The transition from bulging-neck to

\footnotetext{
41. Agora XII, p. 390 . See also Agora XXIX, p. 451, where the stated provenance of the amphoras from deposit F 17:3 (the wall of a well filled after 315 в.c.) provides a terminus ante quem for this amphora. The shapes and dimensions of the Agora amphora and amphora BE2004/4.1 from Chios wreck $\mathrm{A}$ are similar. The Agora amphora's dimensions are overall H. 0.947, max. Diam. 0.332, handle H. 0.342 m. We thank Carolyn Koehler and Susan Rotroff for their assistance in compar-
}

ing these amphoras to those of Chios wreck $A$.

42. Lawall 1998b, p. 78.

43. Grace 1979; Lawall 1998b, p. 81.

44. Mattingly 1981, p. 80; Wallace 1986, pp. 88-89. See also Koehler 1982, pp. 284-285.

45. Mattingly 1981, p. 80; Barron 1986, pp. 96, 98.

46. Hardwick 1993, p. 216; Mattingly 1993, p. 102; Schönhammer 1993, pp. 189-191; Lawall 1998b, pp. 94-95.
47. Hardwick 1993, pp. 216-218, 220.

48. Hornblower 2002, p. 233.

49. Peake 1997; Ruzicka 1998, p. 60; Hornblower 2002, pp. 175, 256.

50. Ashton et al. 2002, p. 216. The output of several other regional mints followed the Chian standard in the early 4th century в.c., including Knidos, Kos, Samos, Kyzikos, Thasos, Ephesos, Miletos, and Rhodes. See Ashton et al. 2002, pp. 242-243. 
straight-neck amphoras around the time of the Athenian Standards Decree has been linked to the shift to an Attic standard measure, presumably in the 420s. To cut ties with the defeated Athenians after the 412 в.c. revolt, the Chians might have changed amphora measures back to their own standard of seven Chian choes ${ }^{51}$ while maintaining the new straight-necked amphora style. From two surviving Chian wine measures, Forrest measured the volume of a Chian chous as $2.881 .{ }^{52}$ Seven Chian choes therefore equal 20.161 , so we would expect to see amphora capacities in this range. Some evidence for this capacity change exists in Chian amphoras excavated in a mid-4th-century context in the lower Don River region. Brashinskii notes that the capacities of the Don River jars range from 18.6 to $20.21 . .^{53}$ As Lawall points out, definite conclusions about this possible capacity change must wait until a larger sample size of Chian amphoras dating before and after the Athenian Standards Decree can be investigated. ${ }^{54}$

Amphora BE2004/4.1 (Fig. 12) recovered from Chios wreck A adds one more data point to this debate. As noted above, the volume to the base of the neck is 19.01 , and the total volume to the rim is 22.01 . Docter tentatively suggests amphoras were filled halfway up the neck of the jar. ${ }^{55}$ If this Chian jar were filled halfway up its neck, the resulting volume would be 20.51 , or within $2 \%$ of seven Chian choes. However, it is statistically unsound to base conclusions about the entire class of Chian amphoras from this wreck on a single sample. ${ }^{56}$ To verify a capacity standard for this style of Chian amphora, additional measurements will be required from the amphoras on this shipwreck and other contemporary sites.

Chian products were traded extensively in the Classical and Hellenistic eras ${ }^{57}$ Excavations of 5th-century strata in Athens and Corinth show large quantities of Chian amphoras, and the island's amphoras have been found in the southern Mediterranean at Naukratis in the Nile Delta, ${ }^{58}$ and farther eastward, on Cyprus. ${ }^{59}$ Evidence from excavations in the northern Black Sea area indicates markets for Chian products in that region during the 4th century B.C., and papyri record that Chios was a port of call for ships trading between Alexandria and the Black Sea during the 3rd century в.с. ${ }^{60}$ Additionally, Chian amphoras have been recovered from several shipwrecks; as Carlson notes, this may indicate that Chian products were widely traded, or it may simply reflect the fact that the distinctive Chian amphoras are 309.

51. Boardman 1958-1959, pp. 306,

52. Forrest 1956, p. 64. One of these Chian wine measures was on display at the Chios Archaeological Museum at the time we were preparing this manuscript; see ArchontidouArgyri and Kyriakopoulou 2000, pp. 160-161.

53. Brashinskii 1980, pp. 16-17; see also Whitbread 1995, pp. 36-37. Additionally, a Chian cap-toed amphora excavated in the harbor at Athlit, Israel, had a capacity of 17.21 , and a later Chian pointed-toe amphora re- covered in the sea off Ashkelon, Israel, had a capacity of 20.51 . No further information is available regarding these finds. See Zemer 1977, pp. 3739.

54. Lawall 2000, p. 7.

55. Docter 1990, p. 155.

56. An interesting discussion of problems in determining amphora capacities and volume standards appears in Matheson and Wallace 1982, esp. p. 300, n. 21.

57. See Empereur and Garlan 1987, 1992, 1997; Drougou, Zervoudaki, and Touratsoglou 1998; Marangou-Lerat
2000; Garlan 2002. The best synthesis of Chian trade in the 5 th century, based on a study of amphoras, is Lawall 1998 b.

58. Archontidou-Argyri and Kokkinoforou 2004, p. 93.

59. A wreck with a cargo of similar Chian amphoras was located and briefly studied in 2007 off the coast of southeast Cyprus (Stella Demesticha, pers. comm.) See also ArchontidouArgyri and Kokkinoforou 2004, pp. 9295.

60. Sarikakis 1986, pp. 121-123. 
easily recognized and therefore more frequently reported than other types. ${ }^{61}$

Chian amphoras excavated from most sites have been interpreted as wine containers, although a few (possibly reused) examples recently studied by archaeologists were found to carry other products. ${ }^{62}$ From ca. 500 в.c. until the Roman period, an amphora accompanied by a bunch of grapes was a persistent feature on Chian coinage. This has been interpreted as an advertisement for the island's wine. ${ }^{63}$ Ancient writers across the centuries noted the quality of Chian vintages. Strabo declared that the best Greek wine was produced in Ariusia, the mountainous northwestern region of the island (Strabo 14.1.35); and Pliny noted that Caesar provided Chian wine at his triumphal banquets ( $H N 14.16 .97)$. Theopompos credited the Chians with the invention of "dark" or "black" wine, as differentiated from white or yellow wine. ${ }^{64}$ In the Deipnosophistae, Athenaeus quoted other ancient authors' claims that Chian wine was best of all, again singling out the Ariusian variety (Ath. 1.26b, 1.29e, and esp. 1.32f). The ancient texts indicate that the distinctive Chian wine found a wide and eager market throughout the Greek world for centuries.

However, amphora BE2004/4.1 was not lined with resin, an indication that it probably did not hold wine. To determine its contents, we extracted a small $(<1 \mathrm{~g})$ sample of ceramic from the interior wall of the jar and subjected it to molecular biological analysis, an unprecedented technique fully described elsewhere. ${ }^{65}$ These analyses revealed ancient DNA of olive and oregano. ${ }^{66}$ This result is intriguing; it demonstrates that this type of amphora did not contain wine exclusively in its first use for export. Some portion of this ship's cargo was composed of olive products carried in Chian amphoras. Additional samples must be collected and analyzed from more amphoras on this shipwreck before broader conclusions about the cargo can be drawn.

The capacity of the second amphora recovered from Chios wreck A, unattributed amphora BE2004/4.4, is 32.41 at the base of the neck (11.2 Chian choes of 2.881 each). The total internal volume measured at the rim is 331 (11.4 Chian choes). It seems possible that this jar conformed to a different volume standard, perhaps the Attic standard. The exact measure of a standard Attic chous is unknown. ${ }^{67}$ Lang and Crosby's estimate of 3.2761 is generally accepted, often rounded down to 3.20 or $3.261 .^{68}$ If we accept the standard Attic chous as 3.261 , then the unattributed amphora from Chios wreck A measures within $\pm 1 \%$ of 10 Attic choes if filled halfway up the neck. As with the Chian amphora, broader conclusions about the amphoras of this unattributed type on Chios wreck A cannot be made without a larger sample size.

The bottom of amphora BE2004/4.4 contained a small lump of hardened shiny brownish resin. We collected a sample of the resin in May 2006 and submitted it for carbon-14 analysis to the National Ocean Sciences Accelerator Mass Spectrometry Facility (NOSAMS) at Woods Hole Oceanographic Institution. ${ }^{69}$ The radiocarbon date of the resin is 2400 \pm 30 years b.p., calibrated to a calendar date of 410 в.c. \pm 30 years. The calibrated calendar date is somewhat earlier than expected, considering the estimated date of the Chian amphoras on the wreck. ${ }^{70}$ The calibrated
61. Carlson 2004, pp. 142-143.

62. Barron 1986, pp. 98-99. A 5thcentury B.c. Chian amphora recovered from the sea off Knidos contained hundreds of olive pits. However, it is not known if this represents the original contents or the reuse of the jar (Cemal Pulak, pers. comm.). Similarly, a single Chian amphora containing olive pits was recovered from the wreck near Aslan Burnu; see Kerameikos IX, pp. 23-24; and Carlson 2004, p. 139.

63. Hardwick 1993, p. 211.

64. Boardman 1967, p. 252; Whitbread 1995, p. 144.

65. Hansson and Foley 2008. The great potential of this technique lies in its ability to detect the residue of ancient substances in empty amphoras.

66. Hansson and Foley 2008.

67. The Attic kotyle is believed to be 0.2711 and 12 times that volume equals 3.2621 , perhaps equaling an Attic chous.

68. Agora X, pp. 47, 58; Forrest 1956, p. 64; Koehler and Wallace 1987 , p. 55 .

69. We acknowledge the National Science Foundation's support of NOSAMS under NSF Cooperative Agreement no. OCE-9807266.

70. The calibration curve for the Classical period is relatively flat and therefore problematic for radiocarbon analysis of artifacts from this era. 
calendar date range should be tempered with the knowledge that wine sometimes was aged for years in amphoras. In addition, the resin could have been collected and stored for some time before being used to preserve the wine, assuming that the jar did contain wine. ${ }^{71}$ We acknowledge that a radiocarbon date from a single sample can be suggestive, but not conclusive, evidence for the date of the vessel's sinking.

The origin of the amphora type represented by BE2004/4.4 is unknown, but it might have been a location near Chios. There has been some speculation that the type originates on Chios itself. ${ }^{72}$ The unattributed amphora from Chios wreck $A$ shares general similarities with amphoras from the Tektaş Burnu wreck, located only 20 nautical miles away. The correspondence between those amphoras, however, is not exact. Whereas the overall body shape is similar, substantial differences exist in the rim. A range of toe shapes can be seen among the Tektaş Burnu amphoras. None precisely match the toe of the unattributed amphora from Chios wreck $A$, although the bottom half of the rounded teacup, double-beveled toe of Tektaş Burnu amphora lot 0911 does bear some stylistic similarity to the toe of BE2004/4.4. ${ }^{73}$

The variability between the features of the two amphora types may be due to the passage of three-quarters of a century between the two wrecks, or perhaps the amphoras are simply from different production centers. The Tektaş Burnu amphoras were initially termed "pseudo-Samian" and then reconsidered and reclassified as likely being Klazomenian or west Asian.

71. Barron 1986, p. 98.

72. Monakhov 1999, p. 368.

73. Carlson 2004, p. 175, fig. 47.

74. Bass 2002, p. 96; Carlson 2003, p. 586, fig. 5, bottom. See Özyiğit 1990 for amphoras from Erythrai, esp. p. 145. Chios and Erythrai maintained economic, political, and occasional military relations in the 5 th and 4th centuries в.c. Erythrai followed Chios's revolt against Athens in 412 в.C.; stone from Erythrai appears in Classical Chios constructions; and the Persian satrap Mausolos is credited both with refounding Erythrai in the mid-4th century and minting its coins on the Chian standard. Mausolos also entered into a defensive alliance with Chios and other east Greek states in the 350s. The mixed cargo of ceramic material from Chios and Erythraian amphoras on the Tektaş Burnu wreck is another suggestion of links between the two centers.

75. Hansson and Foley 2008.

76. An unresolved problem is the apparent difference in capacity standards between the Chian amphora and the unattributed amphora from Chios wreck A. We hope that future research will help to explain this fact.
Recently, scholars studying that wreck have proposed Erythrai as a possible place of manufacture (Fig. 1) ${ }^{74}$ We encourage amphora specialists to perform additional research into the unattributed amphoras from Chios wreck $A$ in order to establish developmental links to other types and to determine the origin of the type. Recovery of additional examples of the unattributed type may be necessary before firm conclusions can be drawn.

Molecular biological analysis of a ceramic sample from the interior wall of amphora BE2004/4.4 may support an origin of Chios or nearby. Our results show that the jar contains ancient DNA from the Pistacia genus, which includes pistachio nut and mastic. ${ }^{75}$ Given the presence of resin in the jar, we suspect that the DNA might represent mastic. Pliny wrote that Chios was the best-known source of high-quality gum mastic in the ancient world. He differentiated Chian "white mastic" from other mastic-like substances for its color, consistency, and method of collection (HN12.36). This opens the question of whether Chian mastic was a distinct species within a general family of mastic-like substances described in ancient texts. Fresh samples of modern Chian mastic have been collected by the research team, and additional chloroplast genes are being sequenced from that species and others within the Pistacia genus. Successive DNA analyses are now being performed in the hope of further refining the identification of the material in amphora BE2004/4.4. If this jar did contain Chian mastic, it suggests a local origin for the contents of the unattributed amphora, and therefore perhaps the jar itself. ${ }^{76}$

The bathymetric maps and photomosaic of the wreck show the distribution of the amphoras and other artifacts (Figs. 7 and 10). The Chian amphoras form the majority of the visible cargo remains, and they are 
distributed along three-quarters of the length of the wreck beginning at the western end, with a few scattered along the remaining quarter of the site at the eastern end. The unattributed amphoras are located exclusively in the eastern end of the wreck. Since Chian amphoras are located among and perhaps underneath amphoras of the unattributed type, it may be that the Chian amphoras were loaded first, or at the same time as the other amphora variety. This may be a clue to the origin of this other amphora type, providing circumstantial evidence that it could be a Chian style, or else produced somewhere nearby. Another possibility is that the unattributed amphoras were shipped to Chios on another vessel, only to be re-exported by the ship wrecked off Langada. If so, they might have been loaded at the same time as the jars originating on the island. Alternatively, it is possible that the Chian amphoras now in the eastern end of the wreck arrived in their current positions during the wrecking event. If the eastern end of the vessel hit the seafloor first, these Chian amphoras might have tumbled through the ship into the area containing the unattributed amphoras. This might also account for the many crushed jars in that area of the wreck; the effect would have been similar to a bowling ball knocking down tenpins. Intrusive investigation of the wreck may be necessary before these questions can be answered.

We can speculate on the reasons for the vessel's loss from the information collected during the survey. The sonar survey of the area surrounding the wreck site and the high-resolution photographic survey of the wreck itself both indicate a distinct absence of a debris trail. Apparently there was no attempt on the part of the crew to throw cargo overboard during the ship's last minutes. The digital images show no evidence of fire among any of the artifacts observed on the seafloor, nor is any blackening evident on the three artifacts raised in 2004 and 2005. Perhaps the wrecking event occurred suddenly. The island's 1,100 m elevations are located within $12 \mathrm{~km}$ of the wreck site. The terrain funnels violent downdrafts and gusts of wind across the water's surface. The wreck is oriented at a heading of $300^{\circ}$, pointing toward the shore. The winds at Langada have been described as "fluky and gusty," and they would have required ships' helmsmen to pay careful attention while transiting along the coast. ${ }^{77} \mathrm{~A}$ square-rigged Classical vessel sailing on a beam reach would heel, requiring the helmsman to increase the rudder angle to leeward. If a strong gust caught the sails, the helmsman could lose control of the vessel as it swung into and maybe through the wind. This would result in the square sail being taken aback, causing the vessel to heel sharply. In the worst case, this could cause the vessel to take on water over the rail and sink. ${ }^{78}$

The exact place of lading and route of the vessel prior to sinking are unknown, as is the site of 4th-century B.c. amphora production. Analysis of the clay of Chian amphoras suggests it might originate in the beds near Emporio and Armolia, in the southeastern portion of the island (see Fig. 1).$^{79}$ Archaeologists have conducted extensive surveys and excavations on the Kofina ridge to the north and west of modern Chios Town without finding evidence of kilns. Chios holds scores of archaeological sites dating from the Neolithic through the Byzantine periods, ${ }^{80}$ but only two kilns or amphora-production sites have been located. ${ }^{81}$ It has long been suspected
77. Hunt 1946, p. 49.

78. Roberts 1995 , p. 311.

79. Jones 1986, pp. 283, 287-288.

80. See Yalouris 1986.

81. One in the area of Letsaina in the modern town of Chios and a second one in the area of Limnia on the northwest side of the island, near the harbor of Volissos; see ArchontidouArgyri and Kyriakopoulou 2000, pp. 158-159. 
that Classical kilns may underlie and be obscured by modern Chios Town, and in 1986 archaeologists discovered evidence of amphora production within the town. ${ }^{82}$ It is possible that the amphoras from Chios wreck A were loaded aboard the ship at Chios Town, located $15 \mathrm{~km}$ south of the wreck.

Locating additional kiln sites may shed light on the conveyance of agricultural products and transport containers around and from the island. It is not known if empty amphoras were transported to the wine- and oliveproducing areas by boat or cart, or if the liquids were carried across land to points on the shore for loading into amphoras near the ships.

The closest villages to the Classical wreck site are Delphinion and Langada, about $2 \mathrm{~km}$ distant. During a 1954 underwater survey, archaeologists noted the presence of "heaps of Chian amphoras dating from about 400 B.c." in underwater gullies $20 \mathrm{~m}$ deep off the islet of Taurus, just offshore from Delphinion. ${ }^{83}$ More recently, the EUA team located Chian amphora sherds dated earlier than Chios wreck $A$ in the area off Taurus. Remains of harbor installations and scattered potsherds can be found on the main island near Taurus, along with the remains of the Temple of Apollo Delphinios. The Athenians used Delphinion as their naval base in 411-406 B.c. in their actions against the Chians. ${ }^{84}$ It was routinely used as an anchorage or a place of lading in the late 5 th century and throughout the 4th century в.C.

\section{CONCLUSIONS AND FUTURE DIRECTIONS}

We show here that precise, accurate, high-quality nondestructive surveys of shipwrecks at any depth can be delivered within a single day. Our methods and technologies permit the detailed quantification of the physical dimensions, environmental setting, contents, and condition of wreck sites. The data collected on the 70-m-deep Chios wreck A show a site dating to the second half of the 4 th century B.c. that measures $21 \times 8 \times 1.4 \mathrm{~m}$. The wreck's cargo is composed of approximately 350 amphoras in the surface layer, and probably contains additional layers of amphoras under the sediment. The amphoras are of two types, Chian and an unattributed type. One example of each was recovered by EUA and HCMR in 2004. Molecular biological analysis of ceramic samples from the jars indicates the presence of ancient DNA of olive and oregano in the Chian amphora, and Pistacia genus, possibly mastic, in the unattributed amphora. ${ }^{85}$ In addition to the amphoras, five small jugs are evident on the site, perhaps representing a secondary cargo consignment or a part of the crew's galley ware. One example of these small jugs was recovered during the 2005 season. The wreck site and its artifacts show no evidence of fire, and there is no debris trail near the wreck. The vessel sank close to shore in an area known for unpredictable wind gusts. All evidence suggests a sudden sinking event.

Although a fair amount is known about the political and economic

82. Anderson 1954, p. 123; Jones 1986, p. 284; Tsaravopoulos 1986.

83. Garnett and Boardman 1961, p. 106.

84. Roisman 1987, p. 29.

85. See Hansson and Foley 2008. history of Chios in the 5 th century B.c., archaeological and textual evidence is scant for Chios in the second half of the 4th century B.c. The information derived from Chios wreck $A$ begins to fill that gap. Based on the visual evidence collected in 2005 , the wreck carries a cargo dominated by Chian amphoras. Only two amphora types are evident on the wreck, 
though we acknowledge that unseen cargo may differ in composition from the observable layer. In any case, the ship carried a cargo outbound from Chios. Given the wreck's proximity to the island of origin and the large number of amphoras found on it, it is logical to assume that this was the first time these Chian amphoras were used. This amphora type typically is associated with the wine trade; however, evidence of original amphora contents delivered by our new technique to detect ancient DNA proves that some portion of the cargo carried in these amphoras was composed of olive products, not wine. We therefore question the assumptions made in the past regarding the contents of unlined Chian amphoras. Classical-era Chian amphoras are quite distinctive and therefore commonly identified in terrestrial and underwater sites. We plan to conduct additional DNA studies of Chian amphoras from Chios wreck $A$ and other sites. If access to a significant number of these jars can be secured, it may be possible to trace Chian agricultural export production through a long time span.

During the 2005 expedition, a second wreck was also partially surveyed. The site was reported to the EUA prior to the 2005 project, but had not been investigated before our survey. Chios wreck $B$ is a late-2nd- to early1st-century B.c. wreck located off the west coast of Chios near Lithi. It is marked by a scatter of approximately 40 amphoras that all appear to be of the Dressel 1C type (Will Type 5). The amphoras lie along the bottom of a steep, rocky slope at a depth of 36-42 $\mathrm{m}$. The site has been disturbed by rock slides and possibly wave action, and it is heavily encrusted in marine growth. One example of a Dressel 1C amphora was collected, and it bears an incuse stamp on its rim (Fig. 4). The 2005 survey of this wreck was cut short by damage to the AUV, but EUA archaeologists continue to study this site.

The 2005 Chios project points to the future potential of rapid, autonomous archaeological survey regardless of depth, but there will always be a place for archaeological divers when water depth permits. With autonomous robotic methods complementing standard shallow-water practices, divers may be freed from mundane and time-consuming mapping tasks, allowing them to concentrate instead on excavation, fine manipulation, and archaeological interpretation. Divers should focus on archaeological questions that cannot be answered by means of robotic technologies and methods. For instance, our procedures for retrieving ancient DNA from amphoras entail bringing the jars to the surface for sampling. In shallow waters, this is best performed by humans. We envision DNA analysis of original amphora contents becoming a common tool for archaeologists. Through the study of ancient DNA remains, archaeologists will be able to draw more precise conclusions about the use of amphoras, agricultural production, and patterns of ancient trade.

The 2005 project demonstrates that in-situ survey methods offer great promise, but cannot yet answer all of the questions archaeologists ask. A combined approach of remote sensing, artifact recovery, and perhaps excavation offers the best balance. The in-situ data recorded in 2005 relate the wreck's environmental context, size, shape, and general composition. From 
these data archaeologists can estimate the wreck's state of preservation, its age, and the origin of its amphora cargo. In contrast, analyses performed on the artifacts recovered in 2004 generate specific conclusions. Detailed examination of artifacts helps to narrow the date of sinking and provides amphora volumetric information. Pioneering molecular biological investigations of the amphoras' contents provide important new information about ancient trade goods. Today it is still necessary to combine in-situ and intrusive methods for comprehensive understanding of underwater archaeological sites; in the future that may change.

Many of the technologies and methods described here are in their infancy. The next generations of more sensitive chemical and environmental sensors are in the final stages of development at WHOI, and they can detect a wide range of compounds at very low concentrations. Combined with precision navigation, chemical maps will provide unprecedented understanding of shipwrecks' physical environments. Eventually, they may be able to discern the materials contained within the wrecks. The novel digital-image mapping techniques outlined here deliver three-dimensional photomosaics and pixel-resolution maps of sites. Soon this technique will be able to generate these data products in near real time. Likewise, new highfrequency acoustic imaging sensors can be utilized for archaeology, making it possible to accurately measure the volume of objects on the seafloor. In future projects, we hope to determine the volumes of a statistically significant number of amphoras on a wreck through acoustic and optical digital imaging, with the intent of assessing capacity standards without removing the artifacts from their archaeological contexts.

For archaeological investigations in deep water, AUV surveys offer benefits over towed sonar surveys and ROV operations. A fast-running AUV can survey two to three times as much seafloor in a more systematic manner than a towed system, and it can produce better data by maintaining an optimal altitude over the terrain during the survey. Multiple AUVs can be operated from a single ship, again increasing the amount of coverage and the number of targets identified. Eventually AUVs will be deployed from shore, reducing project costs by eliminating the support ship. Because each seafloor target can be characterized and surveyed in a single day with an AUV, the number of shipwrecks that archaeologists can examine will increase significantly. Presented with data sets collected by in-situ sensors, archaeologists will be able to prioritize sites deserving intrusive investigations and better allocate the resources necessary for those operations.

AUVs applied to underwater archaeology may permit us to ask new questions by assessing a statistically significant number of comparable, contemporary sites. Instead of concentrating resources on a single site over many years, as has been the practice in underwater archaeology, soon we will be able to survey dozens of sites in a single field season. This will allow broad study of inter- and intraregional trade, exchange, and contact through time. Combined with the information gleaned from complete excavations of land and underwater sites, these new technologies and methods will fundamentally alter our understanding of the ancient past. 


\section{ACKNOWLEDGMENTS}

The Chios 2005 team thanks colleagues Jonathan Adams, Sir John Boardman, Elizabeth Greene, Maria Hansson, Ross Holloway, Carolyn Koehler, Mark Lawall, Anna Marguerite McCann, and Aristotle Tympas for sharing their knowledge, and the two anonymous Hesperia reviewers whose suggestions greatly improved this manuscript. We thank the two students who participated in the 2005 cruise: Ballard Blair, graduate student in the WHOI-MIT Joint Program; and Christopher Murphy, then a student at Franklin W. Olin College of Engineering and now a graduate student in the WHOI-MIT Joint Program. We gratefully acknowledge the support of the Hellenic Ministry of Culture, the Hellenic Centre for Marine Research, the U.S. National Science Foundation, George Chronis and Vangelis Papathanassiou of HCMR, and the captain and crew of R/V AEGAEO. The SeaBED AUV and the efforts of its team were funded by the Censsis Engineering Research Center under NSF grant no. EEC9986821. We express our sincere appreciation to sponsors Susan and Robert Bishop, Jane and James Orr, and others, whose generosity made this project possible.

The 2005 Chios AUV Shipwreck Survey included participants from the Hellenic Ministry of Culture, Ephorate of Underwater Antiquities (EUA); the Hellenic Centre for Marine Research (HCMR); and the Woods Hole Oceanographic Institution and Massachusetts Institute of Technology (WHOI/MIT).

EUA team: Katerina Dellaporta, Director; and archaeologists Dionysis Evagelistis, Dimitris Kourkoumelis, Paraskevi Micha, and Theotokis Theodoulou.

HCMR team: Dimitris Sakellariou, geologist, Chief Scientist; Theodoros Fotopoulos, engineer, ROV team; Panos Georgiou, geologist; Kostas Katsaros, Thetis pilot, ROV team; Aggelos Mallios, chief diver, ROV pilot, engineer; Prokopis Mantopoulos, engineer, side-scan sonar/sub-bottom profiler; Ioannis Pampidis, engineer, side-scan sonar/sub-bottom profiler; and Spyros Volonakis, head of HCMR underwater activities.

WHOLMIT team: Brian Bingham, engineer, precision navigation; Ballard Blair, graduate student; Richard Camilli, engineer, chemical sensing; Ryan Eustice, engineer, AUV operations and precision mapping; Vicki Ferrini, engineer, software, mapping, and mosaicking; Brendan Foley, archaeologist, project leader; David Gallo, program development; Catherine Giangrande, archaeological conservator and project development; Matthew Grund, engineer, acoustic modems; Neil McPhee, engineer, vehicle systems; David Mindell, engineer, precision navigation; Christopher Murphy, student; Catherine Offinger, logistics and administrative support; James Rakowski, program development; Christopher Roman, engineer, AUV operations and precision mapping; Hanumant Singh, engineer, AUV operations and underwater imaging; Ann Stone, logistics and administrative support; and David Switzer, archaeologist. 


\section{REFERENCES}

Agora = The Athenian Agora: Results of Excavations Conducted by the American School of Classical Studies at Athens, Princeton

$\mathrm{X}=\mathrm{M}$. Lang and M. Crosby, Weights, Measures, and Tokens, 1964.

$\mathrm{XII}=\mathrm{B}$. A. Sparkes and L. Talcott, Black and Plain Pottery of the 6th, 5th, and 4th Centuries B.C., 1970.

$\mathrm{XXIX}=\mathrm{S}$. I. Rotroff, Hellenistic Pottery: Athenian and Imported Wheelmade Table Ware and Related Material, 1997.

Anderson, J. K. 1954. "Excavations on the Kofina Ridge," BSA 49, pp. 123182.

Archontidou-Argyri, A., and M. Kokkinoforou. 2004. Archaeological Collection at Volissos of Chios (Ministry of Culture, 20th Ephorate of Prehistoric and Classical Antiquities), Mytilene.

Archontidou-Argyri, A., and T. Kyria-

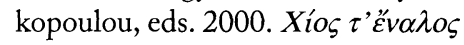

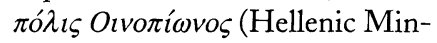
istry of Culture, 20th Ephorate of Prehistoric and Classical Antiquities), Mytilene.

Arribas, A., M. G. Trias, D. Cerda, and J. De La Hoz. 1987. El Barco de El Sec (Calvià, Mallorca): Estudio de los materiales, Mallorca.

Ashton, R. H. J., N. Hardwick, P. Kinns, K. Konuk, and A. R. Meadows. 2002. "The Pixodarus Hoard ( $\mathrm{CH}$ 9.421)," in Coin Hoards IX: Greek Hoards (Special Publications of the Royal Numismatic Society 35), ed. A. Meadows and U. Wartenberg, London, pp. 159-243.

Ballard, R. D., A. M. McCann, D. Yoerger, L. Whitcomb, D. Mindell, J. Oleson, H. Singh, B. Foley, J. Adams, D. Piechota, and C. Giangrande. 2000. "The Discovery of Ancient History in the Deep Sea Using Advanced Deep Submergence Technology," Deep-Sea Research I:47, pp. 1591-1620.

Ballard, R. D., L. E. Stager, D. Master, D. Yoerger, D. Mindell, L. L. Whitcomb, H. Singh, and D. Piechota. 2002. "Iron Age Shipwrecks in Deep Water off Ashkelon, Israel," AJA 106, pp. 151-168.
Barron, J. P. 1986. "Chios in the Athenian Empire," in Chios: A Conference at the Homereion in Chios, 1984, ed. J. Boardman and C. E. Vaphopoulou-Richardson, Oxford, pp. 89103.

Bass, G. F. 2002. "The Excavation of a Fifth-Century в.c. Shipwreck: 1999 Campaign," in 7 th International Symposium on Ship Construction in Antiquity: Pylos, 26, 27, 28, 29 August 1999. Proceedings (Tropis 7), ed. H. Tzalas, Athens, pp. 93102.

Bingham, B. 2003. "Precision Autonomous Underwater Navigation" (diss. Massachusetts Institute of Technology).

Boardman, J. 1958-1959. "Excavations at Pindakas in Chios," BSA 53-54, pp. 295-310.

-1967. Excavations in Chios, 1952-1955: Greek Emporio (BSA Suppl. 6), London.

Brashinskii, I. B. 1980. Grecheskii keramicheskii import na Nizhnem Donu $v V$-III vv. do n.e. [Greek Ceramic Imports to the Lower Don in the 5th-3rd Centuries B.c.], Leningrad.

Bylkova, V. P. 1996. "Excavations on the Eastern Boundary of the Chora of Olbia Pontica," EchCl 40, n.s. 15, pp. 99-118. - 2005. "The Chronology of Settlements in the Lower Dneiper Region, 400-100 B.c.," in Chronologies of the Black Sea Area in the Period c. 400-100 B.C. (Black Sea Studies 3), ed. V. F. Stolba and L. Hannestad, Aarhus, pp. 217247.

Carlson, D. N. 2003. "The Classical Greek Shipwreck at Tektaş Burnu, Turkey," AJA 107, pp. 581-600. . 2004. "Cargo in Context: The Morphology, Stamping, and Origins of the Amphoras from a Fifth-Century B.c. Ionian Shipwreck" (diss. Univ. of Texas, Austin).

Casson, L. 1995. Ships and Seamanship in the Ancient World, Baltimore.

Docter, R. F. 1990. "Amphora Capacities and Archaic Levantine Trade," 
HBA 15-17 (1988-1990), pp. 143188.

Drougou, S., I. Zervoudaki, and I. Tou-

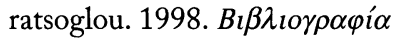
$\varepsilon \lambda \lambda \eta v \imath \kappa \eta ́ \varsigma \kappa \varepsilon \rho \alpha \mu \imath \kappa \dot{\varsigma}$ 1980-1995 I:

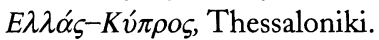

Empereur, J.-Y., and Y. Garlan. 1987. "Bulletin archéologique: Amphores et timbres amphoriques (19801986)," RÉG 100, pp. 58-109.

—. 1992. "Bulletin archéologique: Amphores et timbres amphoriques (1987-1991)," RÉG 105, pp. 176220.

-1997. "Bulletin archéologique: Amphores et timbres amphoriques (1992-1996)," REG 110, pp. 161209.

Ephesos XIII. 2 = P. Sherrer and E. Trinkl, eds., Die Tetragonos Agora in Ephesos: Grabungsergebnisse von archaischer bis in byzantinische Zeit. Ein Überblick: Befunde und Funde klassischer Zeit (Ephesos XIII.2), Vienna 2006.

Eustice, R. M., O. Pizarro, and H. Singh. 2004. "Visually Augmented Navigation in an Unstructured Environment Using a Delayed State History," in Proceedings of the 2004 IEEE International Conference on Robotics and Automation, April 26May 1, 2004, New Orleans, LA, USA 1, Piscataway, N.J., pp. 25-32.

Eustice, R. M., H. Singh, J. J. Leonard, and M. Walter. 2006. "Visually Navigating the RMS Titanic: Conservative Covariance Estimates for SLAM Information Filters," International Journal of Robotics Research 25 , pp. 1223-1242.

Foley, B. P., and R. D. Ballard. 2004. "Amphora Alley II," in McCann and Oleson 2004, pp. 183-194.

Forrest, W. G. 1956. "A Chian Wine Measure," BSA 51, pp. 63-67.

Garlan, Y. 2002. "Bulletin archéologique: Amphores et timbres amphoriques (1997-2001)," RÉG 115, pp. 149-215.

Garnett, R., and J. Boardman. 1961. "Underwater Reconnaissance off the Island of Chios, 1954," BSA 56, pp. 102-113.

Giannikouri, A., V. Patsiada, and M. Philimonos. 2000. “Т $\alpha \varphi \iota \kappa \alpha ́$

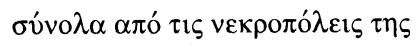

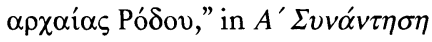
$\gamma \iota \alpha \tau \eta v \varepsilon \lambda \lambda \eta v \imath \sigma \tau \imath \kappa \dot{\eta} \kappa \varepsilon \rho \alpha \mu \varepsilon \imath \kappa \dot{n}$,

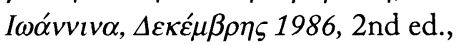
ed. L. Marangou, Rhodes, pp. 6385.

Gordon, R. L. 1996. Acoustic Doppler Current Profiler: Principles of Operation. A Primer, 2nd ed., San Diego.

Grace, V. R. 1979. Amphoras and the Ancient Wine Trade (AgoraPicBk 6), rev. ed., Princeton.

Hadjidaki, E. 1996. "Underwater Excavations of a Late Fifth Century Merchant Ship at Alonnesos, Greece: The 1991-1993 Seasons," BCH 120, pp. 561-593.

Hansson, M. C., and B. P. Foley. 2008. "Ancient DNA Fragments inside Classical Greek Amphoras Reveal Cargo of 2400-Year-Old Shipwreck," JAS 35, pp. 1169-1176.

Hardwick, N. 1993. "The Coinage of Chios from the VIth to the IVth Century B.c.," in Actes du XI Congrès international de numismatique: Organisé à l'occasion du $150^{e}$ anniversaire de la Société Royale de $\mathrm{Nu}$ mismatique de Belgique, Bruxelles, 8-13 septembre 1991,ed. M. Hoc, Louvain-la-Neuve, pp. 211-222.

Hind, J. G. F. 1992-1993. “Archaeology of the Greeks and Barbarian Peoples around the Black Sea (1982-1992)," $A R$ 39, pp. 82-112.

Holt, P. 2003. "An Assessment of Quality in Underwater Archaeological Surveys Using Tape Measures," IJNA 32, pp. 246-251.

Hornblower, S. 2002. The Greek World 479-323 B.C., 3rd ed., London.

Houston, G. W. 1988. "Ports in Perspective: Some Comparative Materials on Roman Merchant Ships and Ports," AJA 92, pp. 553-564.

Hunt, D. W. S. 1946. "An Archaeological Survey of the Classical Antiquities of the Island of Chios Carried Out between the Months of March and July 1938," BSA 41, pp. 30-52.

Jones, R. E. 1986. Greek and Cypriot Pottery: A Review of Scientific Studies, Athens.

Katzev, M. L. 1972. "The Kyrenia Ship," in A History of Seafaring Based on Underwater Archaeology, ed. G. F. Bass, London, pp. 50-52.
Kerameikos IX = U. Knigge, Der Südbügel (Kerameikos IX), Berlin 1976.

Kinsey, J., R. Eustice, and L. Whitcomb. Forthcoming. "Underwater Vehicle Navigation: Recent Advances and New Challenges," in Proceedings of the 7th IFAC Conference on Manoeuvering and Control of Marine Craft, September 20-22, 2006, Lisbon.

Koehler, C. G. 1982. "Amphoras on Amphoras," Hesperia 51, pp. 284292.

Koehler, C. G., and M. B. Wallace. 1987. "Appendix. The Transport Amphoras: Description and Capacities," in C. Pulak and R. F. Townsend, "The Hellenistic Shipwreck at Serçi Limanı, Turkey: Preliminary Report," AJA 91, pp. 49-57.

Lawall, M. L. 1998a. "Bolsals, Mendean Amphoras, and the Date of the Porticello Shipwreck," IJNA 27, pp. 16-23.

1998b. "Ceramics and Positivism Revisited: Greek Transport Amphoras and History," in Trade, Traders, and the Ancient City, ed. H. Parkins and C. J. Smith, New York, pp. 75-101.

2000. "Graffiti, Wine Selling, and the Reuse of Amphoras in the Athenian Agora, ca. 430 to 400 в.c.," Hesperia 69, pp. 3-90. . 2002. "Ilion before Alexander: Amphoras and Economic Archaeology," Studia Troica 12, pp. 197244.

- 2005. "Negotiating Chronologies," in Chronologies of the Black Sea Area in the Period c. 400100 B.C. (Black Sea Studies 3), ed. V. F. Stolba and L. Hannestad, Aarhus, pp. 31-67.

Linder, E., Y. Kahanov, and E. Black, eds. 2003. The Ma'agan Mikhael Ship: The Recovery of a 2400-YearOld Merchantman: Final Report 1, Haifa.

Marangou-Lerat, A. 2000. "Le plus agréable des vins grecs," in L'avventura del vino nel bacino del Mediterraneo, ed. D. Tomasi and C. Cremonesi, Venice, pp. 71-85.

Matheson, P. M., and M. B. Wallace. 1982. "Some Rhodian Amphora 
Capacities," Hesperia 51, pp. 293320.

Mattingly, H. B. 1981. "Coins and Amphoras: Chios, Samos, and Thasos in the Fifth Century B.c.," JHS 101, pp. 78-86.

- 1993. "New Light on the Athenian Standards Decree (ATL 11, D 14)," Klio 75, pp. 99102.

McCann, A. M., J. Bourgeois, E. K. Gazda, J. P. Oleson, and E. L. Will. 1987. The Roman Port and Fishery of Cosa: A Center of Ancient Trade, Princeton.

McCann, A. M., and J. P. Oleson, eds. 2004. Deep-Water Shipwrecks off Skerki Bank: The 1997 Survey (JRA Suppl. 58), Portsmouth, R.I.

Mindell, D. A., and B. Bingham. 2001. "New Archaeological Uses of Autonomous Undersea Vehicles," in Proceedings of the 2001 MTS/IEEE Oceans Conference 1, Piscataway, N.J., pp. 555-558.

Monakhov, S. I. 1999. Grecheskie amfory $v$ Prichernomor'e: Kompleksy keramicheskoi tary VII-II vekov do n.e. [Greek Amphoras in the Black Sea Area: Complexes of Ceramic Containers, 7th-2nd Centuries B.c.], Saratov.

Monakhov, S. I., and E. I. Rogov. 1990. "Amfory nekropolia Panskoe I [Amphoras of the Panskoe I Necropolis]," Antichnye Mir i Arkbeologiia 7, pp. 128-153.

Özyiğit, Ö. 1990. "1988 Y1l Erythai Sondaj Çalışmaları,” Kazı Sonuçları Toplantısı 11, pp. 125-150.

Parker, A. J. 1981. “Stratification and Contamination in Ancient Mediterranean Shipwrecks," IJNA 10, pp. 309-335.

Peacock, D. P. S., and D. F. Williams. 1986. Amphorae and the Roman Economy: An Introductory Guide, London.

Peake, S. 1997. "A Note on the Dating of the Social War," GaR, 2nd ser., 44, pp. 161-164.

Pizarro, O., and H. Singh. 2003. "Toward Large-Area Mosaicing for Underwater Scientific Applications," IEEE Journal of Oceanic Engineering 28, pp. 651-672.
Pulak, C., and R. F. Townsend. 1987. "The Hellenistic Shipwreck at Serçe Limanı, Turkey: Preliminary Report," AJA 91, pp. 31-57.

Roberts, O. T. P. 1995. "An Explanation of Ancient Windward Sailing: Some Other Considerations," IJNA 24, pp. 307-315.

Roisman, J. 1987. "Kallikratidas: A Greek Patriot?" CJ 83, pp. 21-33.

Roman, C., and H. Singh. 2007. "A Self-Consistent Bathymetric Mapping Algorithm," Journal of Field Robotics 4, pp. 26-51.

Rule, N. 1989. "The Direct Survey Method (DSM) of Underwater Survey and Its Application Underwater," IJNA 18, pp. 157162.

Ruzicka, S. 1998. "Epaminondas and the Genesis of the Social War," CP 93, pp. 60-69.

Sakellariou, D., P. Georgiou, A. Mallios, V. Kapsimalis, D. Kourkoumelis, P. Micha, T. Theodoulou, and K. Dellaporta. 2007. "Searching for Ancient Shipwrecks in the Aegean Sea: The Discovery of Chios and Kythnos Hellenistic Wrecks with the Use of Marine GeologicalGeophysical Methods," IJNA 36, pp. 365-381.

Sarikakis, T. C. 1986. "Commercial Relations between Chios and Other Greek Cities in Antiquity," in Chios: A Conference at the Homereion in Chios, ed. J. Boardman and C. E. Vaphopoulou-Richardson, Oxford, pp. 121-131.

Schönhammer, M. 1993. "Some Thoughts on the Athenian Coinage Decree," in Actes du XI Congrès international de numismatique: Organisé à l'occasion du $150^{e}$ anniversaire de la Société Royale de Numismatique de Belgique, Bruxelles, 8-13 septembre 1991, ed. M. Hoc, Louvain-laNeuve, pp. 187-191.

Sciallano, M., and P. Sibella. 1991. Amphores comment les identifier? Aix-en-Provence.

Singh, H., J. Adams, D. Mindell, and B. Foley. 2000. "Imaging Underwater for Archaeology," JFA 27, pp. 319-328.

Singh, H., A. Can, R. Eustice, S. Lerner, N. McPhee, O. Pizarro, and
C. Roman. 2004. "Seabed AUV Offers New Platform for HighResolution Imaging," EOS: Transactions of the American Geophysical Union 85, pp. 289-295.

Singh, H., J. Howland, and O. Pizarro. 2004. "Advances in Large-Area Photomosaicking Underwater," IEEE Journal of Oceanic Engineering 29, pp. 872-886.

Singh, H., L. Whitcomb, D. Yoerger, and O. Pizarro. 2000. "Microbathymetric Mapping from Underwater Vehicles in the Deep Ocean," Computer Vision and Image Understanding 79, pp. 143-161.

Tsaravopoulos, A. 1986. "H $\alpha \rho \chi \alpha i \alpha$

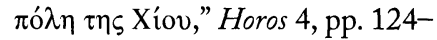
144.

Walker, R. J. 1848. Report of the Secretary of the Treasury in Answer to a Resolution of the Senate Calling for Information in Regard to Wrecks of Vessels Belonging to the United States (30th Congress, 2nd Session, Senate Executive Document 3), Washington, D.C.

Wallace, M. B. 1986. "Progress in Measuring Amphora Capacities," in Recherches sur les amphores grecques (BCH Suppl. 13), ed. J.-Y. Empereur and Y. Garlan, Athens, pp. 8594.

Whitbread, I. K. 1995. Greek Transport Amphorae: A Petrological and Archaeological Study (British School at Athens, Fitch Laboratory Occasional Paper 4), Athens.

Whitcomb, L., D. Yoerger, H. Singh, and J. Howland. 2000. "Advances in Underwater Robot Vehicles for Deep Ocean Exploration: Navigation, Control, and Survey Operations," in Robotics Research: The Ninth International Symposium, ed. J. M. Hollerbach and D. E. Koditschek, London, pp. 439448.

Yalouris, E. 1986. "Notes on the Topography of Chios," in Chios: $A$ Conference at the Homereion in Chios, 1984, ed. J. Boardman and C. E. Vaphopoulou-Richardson, Oxford, pp. 141-168.

Zemer, A. 1977. Storage Jars in Ancient Sea Trade, Haifa. 


\section{Brendan P. Foley}

Woods Hole Oceanographic Institution DEPARTMENT OF APPLIED OCEAN PHYSICS

AND ENGINEERING

DEEP SUBMERGENCE LABORATORY (MS 7)

266 WOODS HOLE ROAD

WOODS HOLE, MASSACHUSETTS O2543-IO5O

bfoley@whoi.edu

\section{Katerina Dellaporta}

Hellenic Ministra of Culture

KLEPSYDRAS 2

IO5 55 ATHENS

GREECE

katerinadellaporta@yahoo.com

\section{Dimitris Sakellariou}

Hellenic Centre for Marine Research INSTITUTE OF OCEANOGRAPHY

P.O. BOX 7 I 2

I9O I3 ANAVYSSOS

GREECE

sakell@ath.hcmr.gr

\section{Brian S. Bingham}

\author{
University of Hawail at Manoa \\ DEPARTMENT OF MECHANICAL ENGINEERING \\ 2540 DOLE STREET \\ HOLMES HALL 304 \\ HONOLULU, HAWAII 96822-2303 \\ bsb@hawaii.edu
}

\section{Richard Camilli}

Woods Hole Oceanographic Institution DEPARTMENT OF APPLIED OCEAN PHYSICS

AND ENGINEERING

DEEP SUBMERGENCE LABORATORY（MS 7)

266 WOODS HOLE ROAD

WOODS HOLE, MASSACHUSETTS O2543-IO5O

rcamilli@whoi.edu
Ryan M. Eustice

University of Michigan

DEPARTMENT OF NAVAL ARCHITECTURE

AND MARINE ENGINEERING

DEPARTMENT OF ELECTRICAL ENGINEERING AND COMPUTER SCIENCE

204 NA\&ME BUILDING

2600 DRAPER DRIVE

ANN ARBOR, MICHIGAN 48IO9-2I45

eustice@umich.edu

\section{Dionysis Evagelistis}

Hellenic Ministry of Culture

EPHORATE OF UNDERWATER ANTIQUITIES

KALLISPERI 30

II 742 ATHENS

GREECE

\section{Vicki Lynn Ferrini}

\section{Lamont-Doherty Earth Observatory of Columbia University}

MARINE GEOLOGY AND GEOPHYSICS DIVISION 6I ROUTE 9W

PALISADES, NEW YORK IO964-8000

ferrini@1deo.columbia.edu

\section{Kostas Katsaros}

Hellenic Centrefor Marine Research P.O. BOX 7 I 2

I9O I3 ANAVYssos

GREECE

katsaros@ath.hcmr.gr

\section{Dimitris Kourkoumelis}

Hellenic Ministru of Culture EPHORATE OF UNDERWATER ANTIQUITIES KALLISPERI 30

II 72 ATHENS

GREECE

kourkou@hol.gr 
Aggelos Mallios

Hellenic Centre for Marine Research P.O. BOX 7 I 2

I9O I3 ANAVYsSos

GREECE

amallios@ath.hcmr.gr

\section{Paraskevi Micha}

Hellenic Ministry of Culture

EPHORATE OF UNDERWATER ANTIQUITIES

KALLISPERI 30

II7 42 ATHENS

GREECE

paraskevi.micha@eea.culture.gr

\section{David A. Mindell}

Massachusetts Institute of Technology PROGRAM IN SCIENCE, TECHNOLOGY, AND SOCIETY

BUILDING E-5I

77 MASSACHUSETTS AVENUE

CAMBRIDGE, MASSACHUSETTS O2I39-430I

mindell@mit.edu

\section{Christopher Roman}

UNIVERSity OF RHOde ISLAND,

NarragansetT Bay Campus

DEPARTMENT OF OCEANOGRAPHY

SOUTH FERRY ROAD

NARRAGANSETT, RHODE ISLAND O2882-II58

cnr@gso.uri.edu

\section{Hanumant Singh}

Woods Hole Oceanographic Institution DEPARTMENT OF APPLIED OCEAN PHYSICS AND ENGINEERING DEEP SUBMERGENCE LABORATORY (MS 7) 266 WOODS HOLE ROAD WOODS HOLE, MASSACHUSETTS O2543-IO5O

hsingh@whoi.edu

\section{David S. Switzer}

\section{Plymouth State Univerity} DEPARTMENT OF SOCIAL SCIENCE ROUNDS HALL

I7 HIGH STREET

PLYMOUTH, NEW HAMPSHIRE 03264 -I 595

dswitzer@plymouth.edu

\section{Theotokis Theodoulou}

Hellenic Ministry of Culture EPHORATE OF UNDERWATER ANTIQUITIES

KALLISPERI 30

II 742 ATHENS

GREECE

t_theotokis@hotmail.com 